ISSN 1996-1944

www.mdpi.com/journal/materials

Review

\title{
Advanced Electrodes for High Power Li-ion Batteries
}

\author{
Karim Zaghib ${ }^{1, *}$, Alain Mauger ${ }^{2}$, Henri Groult ${ }^{3}$, John B. Goodenough ${ }^{4}$ and \\ Christian M. Julien ${ }^{3}$
}

1 Energy Storage and Conversion, Hydro-Québec Research Institute, 1800 Boul. Lionel-Boulet, Varennes, Québec, J3X 1S1, Canada

2 Institut de Minéralogie et Physique des Milieux Condensés, Université Pierre et Marie Curie, 4 place Jussieu, Paris Cedex 05, 75252, France; E-Mail: alain.mauger@impmc.jussieu.fr

3 Physicochimie des Electrolytes, Colloïdes et Sciences Analytiques, Université Pierre et Marie Curie, 4 place Jussieu, Paris 75005, France; E-Mails: henri.groult@upmc.fr (H.G.); christian.julien@upmc.fr (C.M.J.)

4 The University of Texas at Austin, Austin, TX 78712, USA;

E-Mail: jgoodenough@mail.utexas.edu

* Author to whom correspondence should be addressed: E-mail: zaghib.karim@ireq.ca; Tel.:+1-450-652-8019.

Received: 18 February 2013; in revised form: 11 March 2013 / Accepted: 12 March 2013 / Published: 15 March 2013

\begin{abstract}
While little success has been obtained over the past few years in attempts to increase the capacity of Li-ion batteries, significant improvement in the power density has been achieved, opening the route to new applications, from hybrid electric vehicles to high-power electronics and regulation of the intermittency problem of electric energy supply on smart grids. This success has been achieved not only by decreasing the size of the active particles of the electrodes to few tens of nanometers, but also by surface modification and the synthesis of new multi-composite particles. It is the aim of this work to review the different approaches that have been successful to obtain Li-ion batteries with improved high-rate performance and to discuss how these results prefigure further improvement in the near future.
\end{abstract}

Keywords: positive electrode; lithium nano titanate; Li-ion batteries; encapsulation 


\section{Introduction}

Sony Energytec commercialized the first Li-ion battery equipped with a $\mathrm{LiCoO}_{2}$ cathode element in 1990 [1]. This battery is still used for portable applications, but fails to be used for applications demanding more power, such as electric and hybrid vehicles, mainly for safety reasons [2,3]. Since then, other cathode elements have been proposed; they can be divided into three different families. One is the family of lamellar compounds to which $\mathrm{LiCoO}_{2}$ belongs, obtained by the multi-ion substitution of $\mathrm{Co}$. The archetype of this family is $\mathrm{LiNi}_{1 / 3} \mathrm{Mn}_{1 / 3} \mathrm{Co}_{1 / 3} \mathrm{O}_{2}$ (LNMC) first introduced by Ohzuku's group in 2001 as a candidate cathode material [4,5]. The role of $\mathrm{Mn}$ is to order the Li; Ni is the electrochemically active element. Co is still needed to avoid the antisite defect corresponding to $\mathrm{Ni}^{2+}$ on the $\mathrm{Li}^{+}$site [6] facilitated by the fact that $\mathrm{Li}^{+}$and $\mathrm{Ni}^{2+}$ ions have almost the same ionic radius; antisite defects damage the electrochemical properties where the defect concentration exceeds 2 at. \% [7].

The second family is the olivine group, the archetype of which is $\mathrm{LiFePO}_{4}$ (LFP) [8]. However, the low intrinsic electronic conductivity postponed its use, until the problem was solved by coating the particles with conductive carbon [9], which has been a remarkably successful surface modification. A few additional years were required before the material could be freed from any impurity [10]. Since then, the material has been extensively studied. The physical and electrochemical properties as well as the surface and size effects have been reviewed recently [11-14]. For the purpose of the present work, we can summarize the state-of-the-art by saying that there are now different synthesis routes at the industrial scale that make possible the preparation of $\mathrm{LiFePO}_{4}$ particles of different sizes, from submicron to the nano-range depending on the use that is targeted, that are free of any impurity. We only redirect the reader to these prior reviews for more information.

On another hand, the other members of the $\mathrm{LiMPO}_{4}$ family with $M$ any mixing of $\mathrm{Mn}, \mathrm{Ni}, \mathrm{Fe}, \mathrm{Co}$ are still not yet competitive with $\mathrm{LiFePO}_{4}$, despite many efforts. The substitution of Fe by these other transition-metal elements aims to increase the energy density since the $M^{2+} / M^{3+}$ redox potential vs. $\mathrm{Li}^{+} / \mathrm{Li}$ increases with the atomic number: to 3.4, 4.1, 4.8 and $5.1 \mathrm{~V}$ for $M=\mathrm{Fe}, \mathrm{Mn}, \mathrm{Co}, \mathrm{Ni}$, respectively. The two last voltages exceed the stability window of the organic electrolytes presently available, so attention has been focused on $\mathrm{LiMnPO}_{4}$ (LMP) because $4.1 \mathrm{~V}$ is still lower than the highest occupied orbital (HOMO) of the conventional organic electrolyte and its theoretical energy density is larger $\left(701 \mathrm{mWh} \mathrm{g}^{-1}\right.$, against $586 \mathrm{mWh} \mathrm{g}^{-1}$ in LFP). In practice, however, the results are disappointing because its intrinsic electronic conductivity is even smaller than that of LFP [15]. Therefore, the only hope to make it competitive as a cathode element is to follow the same recipe that proved successful for LFP, i.e., decrease the size of the particles to the nano-scale and coat the particles with conductive carbon. Indeed, LMP particles of size $\sim 50 \mathrm{~nm}$ have been obtained by different synthesis routes: solid-state reaction in molten hydrocarbon [16], polyol synthesis [17,18], spray pyrolysis plus ball milling [19]. The best result has been obtained by Choi et al. who synthesized LMP nanoplates with a thickness of $50 \mathrm{~nm}$ that are assembled and grown into nanorods along the (010) direction in the (100) plane [20]. A capacity of $168 \mathrm{mAh} \mathrm{g}^{-1}$ at very low rate $\mathrm{C} / 50$ obtained in this case is close to the theoretical value and is about the same as the capacity obtained for LFP. At faster rates, however, which are essential for electric vehicles that require high power supplies, LMP still cannot compete with LFP because the carbon coating of LMP turns out to be more difficult than that of LFP. The reason is that Fe is very reactive with carbon [21,22] while Mn is not. Indeed, despite 
many efforts made to obtain C-LMP, the capacity remains smaller than that of LFP; it is limited to 130-140 $\mathrm{mAh} \mathrm{g}^{-1}$ at $\mathrm{C} / 10$ rate, and such values are reached only if the particles are immersed in a huge quantity of carbon, typically $20 \mathrm{wt} \%$ [23] up to $30 \mathrm{wt} \%$ [24,25]; the carbon cannot exceed a few wt $\%$ in commercial batteries.

The third family consists of spinel compounds, the archetype being $\mathrm{LiMn}_{2} \mathrm{O}_{4}$. This material has been used as a cathode element in electric-car Li-ion batteries; however, it suffers from the dissolution of manganese in the electrolyte, which reduces the calendar life, especially upon use above room temperature. Moreover, $\mathrm{LiMn}_{2} \mathrm{O}_{4}$ suffers from a reduction of the cycling life at high C-rate. As a consequence, LFP increasingly replaces this compound. The main attention today is focused on another spinel structure, $\mathrm{LiMn}_{1.5} \mathrm{Ni}_{0.5} \mathrm{O}_{4}(\mathrm{LMN})$, which is of great interest because it provides access to the $\mathrm{Ni}(\mathrm{IV})-\mathrm{Ni}(\mathrm{II})$ formal valences at about $4.7 \mathrm{~V}$ vs. $\mathrm{Li}^{+} / \mathrm{Li}$ [26,27]. However, cathode/electrolyte surface reactions lead to degradation in the electrochemical performance [28].

The recent works that are reviewed here have been guided by the following strategies. Now that it is possible to reduce the concentration of the antisite defects in the layered LNMC to a negligible amount, progress may come from surface modification in order to cure the disorder of the surface layers; surface disorder is responsible for an increase of the electronic and ionic resistivity. For LFP, which is already conquering the market for the new generation of hybrid and electric vehicles, progress may come from the reduction of the cost of the synthesis of nanoparticles by new synthetic methods [29], or by optimizing more expensive synthesis routes such as the hydrothermal process that make possible the tuning of the shape of the particles (see [30] and references therein). To improve the energy density of cathode elements in the near future, however, the efforts have been targeted to increasing the electrochemical properties of the LMP and LMN particles that are penalized by surface problems, i.e., by carbon coating in the first case, by eliminating the solid-electrolyte interface (SEI) phase in the second case. A solution that has been found is first to coat the particles with a protective layer of LFP, to take advantage of the remarkable stability of this material, and then to coat the particles with a layer of conductive carbon, taking advantage of the $\mathrm{Fe}-\mathrm{C}$ affinity.

The anode of the commercialized Li-ion batteries with high power is graphite because of its low potential with respect to $\mathrm{Li}^{+} / \mathrm{Li}$ and high energy density with the formation of $\mathrm{LiC}_{6}$. However, a graphite anode limits not only the rate of charge, but also the discharge power density. The graphite layers are fragile and the insertion of lithium between the layers results in an increase of the lattice volume, which may partially break the particles and alter the SEI passivation layer. For instance, Garcia et al. [31] have shown that large stresses develop at high-rate discharge and contribute to the mechanic failure of the graphite electrode. The fracture of the carbon particles [32] is expected to occur above $6 \mathrm{C}$ rate [33]. In addition, at a high charging rate, Li plating on the graphite electrode is inevitable, leading to thermal instability, capacity fade and cell failure [34-37]. Therefore, efforts have been made to replace graphite with $\mathrm{Li}_{4} \mathrm{Ti}_{5} \mathrm{O}_{12}$ (LTO). This lithium titanate with a spinel structure exhibits a stable operating voltage of $1.5 \mathrm{~V}$ vs. lithium [38-40], which is within the commercial-electrolyte window. Moreover, the dilatation of the lattice of LTO upon lithiation is almost zero; the stress during cycling is also negligible, so that no crack of the particles is expected upon cycling. The absence of resistive SEI layer is another advantage that makes this material avoid all the factors mentioned above that limit the power density with a graphite electrode. The capacity is much smaller than that of graphite, but since it is about the same as that of the cathode elements, this 
limitation is not severe. The main drawback comes from the energy density because the operating voltage of the cell is decreased by the $1.5 \mathrm{~V}$ with $\mathrm{LTO} v s . \mathrm{Li}^{+} / \mathrm{Li}$. This feature is prohibitive for some applications like fully electric vehicles, for instance, but not for applications that demand more power than energy, such as hybrid vehicles. The recent results obtained on LFP//LTO cells are very promising and are also reviewed hereunder. The last part of this paper is devoted to a discussion of expectations for the improvement in the performance of Li-ion batteries that can be expected in the near future.

\section{Surface Modification}

The coating of $\mathrm{LiFePO}_{4}$ with carbon is a remarkable example of surface modification. The resulting effect was not detected immediately since the carbon coating was intended to put at the surface of the particles a conductive layer percolating through the powder to transport electrons between the particles and the current collector. Indeed, the first benefit is that an electron reaching the surface of the particle during the charging process can be transported to the collector via the percolating carbon matrix, limiting the slow electron path inside LFP to particles of small radius. It was later realized that the choice of the carbon precursor must be an organic compound because the carbon used for the coating also releases the hydrogen species of the organic substance to act as a reducing agent, thus avoiding the formation of $\mathrm{Fe}^{3+}$-based impurities [41]. Only recently, however, it was realized that the carbon deposit also modifies the surface of the particles as it cures the intrinsic disorder of the 3-nm-thick surface layer [22-29] as a result of the combined effects of $\mathrm{Fe}-\mathrm{C}$ affinity and annealing; the carbon is deposited at $650-700{ }^{\circ} \mathrm{C}$. The $\mathrm{Fe}-\mathrm{C}$ affinity is fortunate since the surface structural disorder is damaging to both the electronic and ionic conductivity.

For lamellar compounds, the electronic conductivity is not a problem. Nevertheless, the delivered capacities of these compounds fade when a high-rate current density is applied [42,43]. Aurbach et al. [44] have suggested that the capacity retention is strongly dependent on the surface chemistry of the particles because of resistive SEI layer. That is why many attempts have been made to protect the surface of $\mathrm{LiCoO}_{2}$ with metal oxides such as $\mathrm{Al}_{2} \mathrm{O}_{3}, \mathrm{TiO}_{2}, \mathrm{ZrO}_{2}, \mathrm{MgO}$ [45-49], or other compounds such as $\mathrm{FePO}_{4}$ [50], $\mathrm{LiFePO}_{4}$ [51], and $\mathrm{Li}_{4} \mathrm{Ti}_{5} \mathrm{O}_{12}$ [52]. In particular, the coating with $\mathrm{ZrO}_{2}$ improves the capacity retention of $\mathrm{LiCoO}_{2}$ during high-potential cycling [49]. Similar efforts have recently made for LNMC by covering the particles with several substances such as $\mathrm{LiAlO}_{2}$ [53] and $\mathrm{Al}_{2} \mathrm{O}_{3}$ [54]. The carbon coating that is so successful for LFP also seems efficient to improve the cycle life of Li-ion batteries with LNMC [55] and $\mathrm{LiCoO}_{2}$ as well [56]. However, the lack of surface analysis makes questionable the nature of the passivation layer and the existence of a carbon deposit. The role of carbon has been detailed only recently [57]. In the reported work [57], LNMC with an average particle size of $250 \mathrm{~nm}$ was first synthesized. One part of the powder was mixed with a organic substance such as sucrose and starch followed by an annealing process at moderate temperature $\left(700^{\circ} \mathrm{C}\right)$, a procedure that has been efficient to coat LFP particles with conductive carbon. The addition of sucrose or starch improved performance. However, in our investigation, no carbon could be detected at the surface of the LNMC particles, even by Raman spectroscopy [57], contrary to the prior work [55] that reported a nanolayer of carbon, although much less regular than on LFP. This difference presumably comes from the fact that the amount of carbon in the preparation process was only $3 \mathrm{wt} \%$. The situation is somehow similar to the case of LMP case reported in the introduction, namely carbon coating requires more carbon. This is not important, however, because the electronic 
conductivity of LNMC is sufficiently high so that it does not limit the performance of the cathode. On the other hand, annealing in the presence of sugar has a major effect by curing the disorder of the surface layer, just like the case of LFP. This is evidenced in the Transmission Electron Microscope (TEM) images in Figure 1. Before the introduction sugar, the surface layer, about $5 \mathrm{~nm}$ thick, was strongly disordered, while after heating in presence of sugar, the surface layer was crystallized. Note that the as-grown sample with the disordered surface layer was prepared at temperature as high as $900{ }^{\circ} \mathrm{C}$, while the annealing in presence of sugar was performed at $600{ }^{\circ} \mathrm{C}$ only. Therefore, the crystallization of the surface layer is not a simple thermal annealing effect, i.e., the presence of sugar during the annealing process is responsible for it.

Figure 1. High resolution transmission electron microscopy (HRTEM) features of $\mathrm{LiNi}_{1 / 3} \mathrm{Mn}_{1 / 3} \mathrm{Co}_{1 / 3} \mathrm{O}_{2}$ (LNMC) powders for as-grown (a) and heat treated sample with sucrose at $600{ }^{\circ} \mathrm{C}$ for $30 \mathrm{~min}$ in air (b). (Reprinted with permission from [57]. Copyright 2011 Elsevier.)
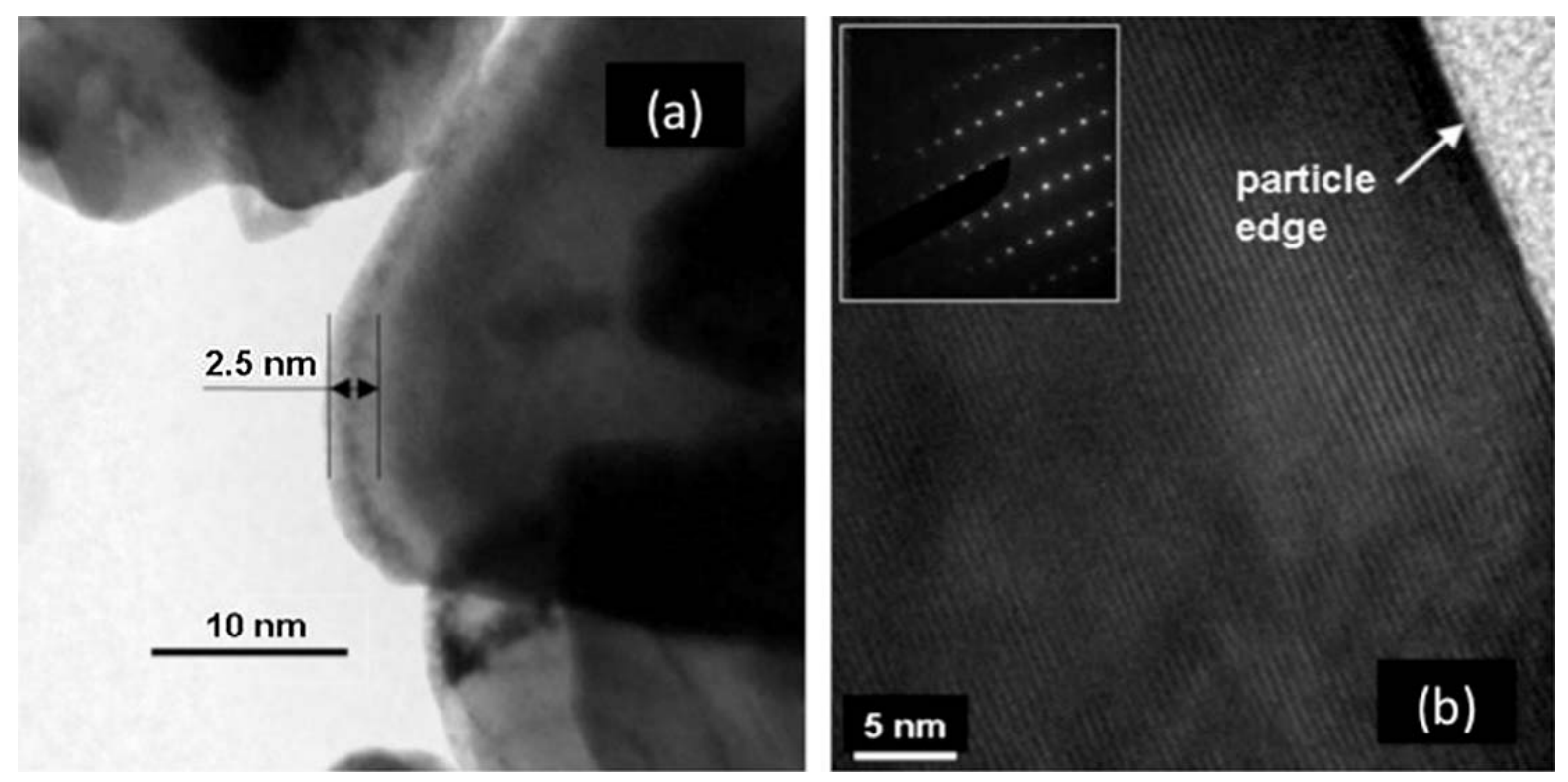

To investigate the effect of this surface modification on the electrochemical properties, two cells were prepared with $\mathrm{Li}$ anode, and $1.0 \mathrm{~mol} \mathrm{~L}^{-1} \mathrm{LiPF}_{6}$ in a mixture of ethylene carbonate (EC) and diethyl carbonate (DEC) $(1: 1, \mathrm{v} / \mathrm{v})$ as electrolyte. The cells differ only by their negative electrode: one cell was prepared with as-grown LNMC anode, the other one with the same LNMC sample after heat treatment in presence of sugar. In addition, the same tap density was used so that a quantitative comparison between the two cells is meaningful. Figure 2a,b shows the potential vs. capacity curves of these cells cycled between 2.5 and $4.2 \mathrm{~V}$ at different C-rates. Heat-treated samples show not only improvement in the discharge capacity values, but also improvement in the capacity retention upon increasing the C-rate value. The polarization in the discharge curve of the surface-modified sample is also reduced in comparison with that of the non-treated sample. The modified Peukert plot in Figure 3 corroborates the better performance of the material after the heat treatment with sugar, the capacity of which is raised to $107 \mathrm{mAh} \mathrm{g}^{-1}$ at $10 \mathrm{C}$, against $81 \mathrm{mAh} \mathrm{g}^{-1}$ before the treatment. 
Figure 2. Discharge cell voltage vs. gravimetric capacity of the $\mathrm{Li} / / \mathrm{LNMCO}$ cells for various C-rate for (a) the as-grown cathode material and (b) heat treated sample with sucrose at $600{ }^{\circ} \mathrm{C}$ for $30 \mathrm{~min}$ in air. (Reprinted with permission from [57]. Copyright 2011 Elsevier.)
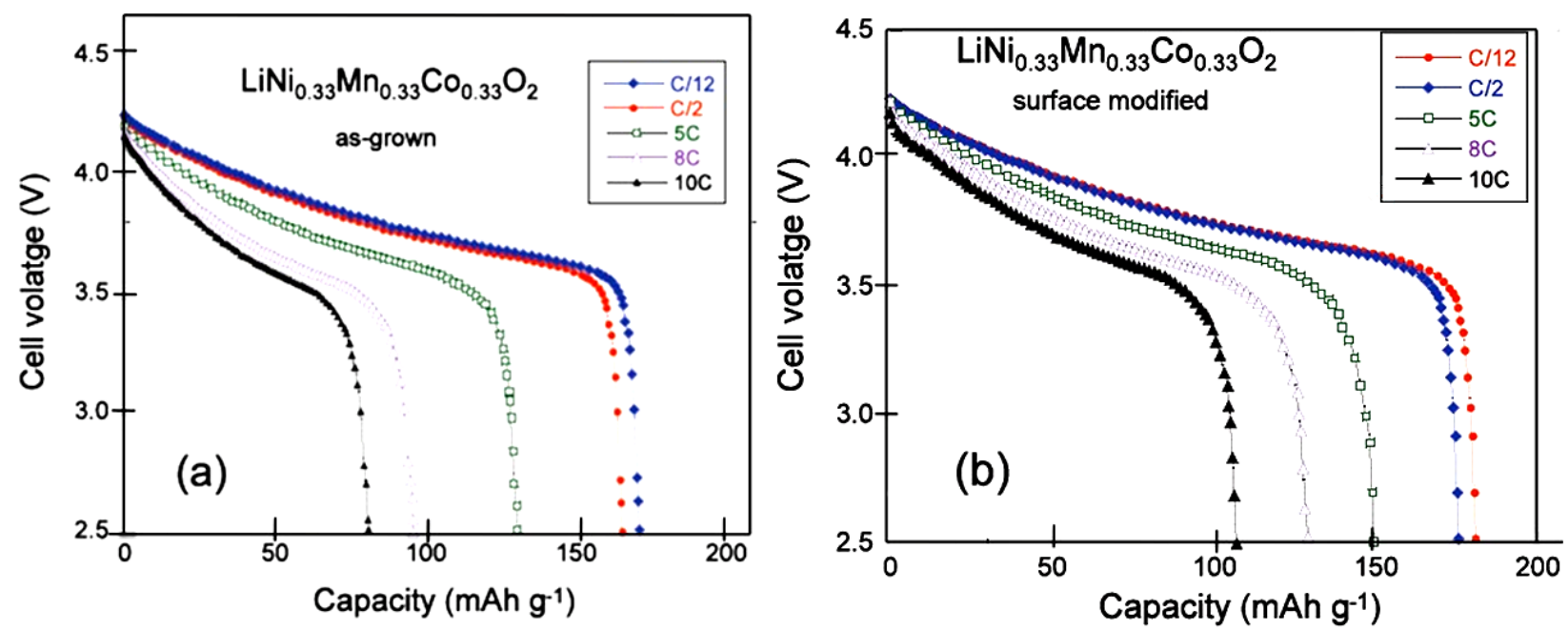

Figure 3. The modified Peukert plots of Li cells for the as-grown and the surface modified LNMC cathode material. (Reprinted with permission from [57]. Copyright 2011 Elsevier.)

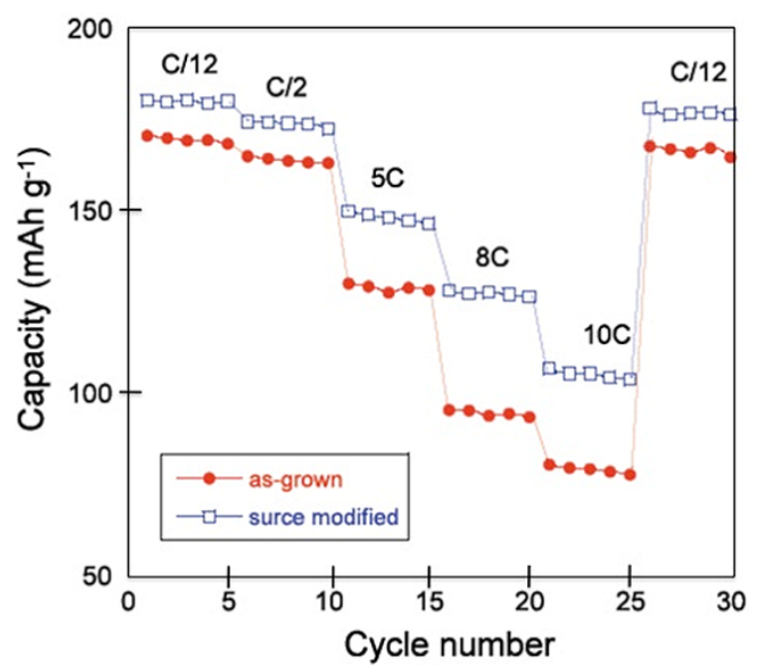

The improvement of the electrochemical performance due to the crystallization of the surface layer can be understood as follows. First, the electronic conductivity is affected by the structural disorder. This has been evidenced by transport experiments that have shown an increase of conductivity when the calcination temperature used in the synthesis process increases from 800 up to around $1000{ }^{\circ} \mathrm{C}$, owing to improved crystallinity of the materials [58]. In fact, a high crystallinity is essential to obtain good electrical conductivity [58]. We can also presume that the disordered layer acts as a diffusion barrier impeding the motion of the $\mathrm{Li}^{+}$ions, but impedance spectroscopy measurements still needs to be done to confirm this presumption. It should be noted that the improvement of the electrochemical properties due to the crystallization of the surface layer is quite comparable to the improvement obtained by coating LNMC with different substances [45,52]. Since, however, no surface analysis has been performed, except in few cases [46,47,51], we can even question whether the improvement is due 
to the coating or to a reconstruction of the surface layer. In any case, the surface modification simply obtained with table sugar is less expensive than a coating with other metal oxides or other compounds.

\section{Multi-Composites}

In the case of olivine compounds, a simple surface modification is not sufficient, because their low electronic conductivity requires a conductive coating of the particles. We have already pointed out in the introduction that the coating is easily done to obtain C-LFP, but more difficult in the case of LMP. One solution in this latter case consists of synthesizing the LMP particles first and coating them in a second step with a thin layer of LFP following the synthesis process described in [59]. The energy-dispersive X-ray image map in Figure 4a of Fe and Mn elements in one particle shows that this coating has been successful. It is then straightforward to coat these composite particles with carbon (third step in the synthesis process), following the same procedure as the one used for LFP. The only difference is that the sintering temperature, which is usually $650-700{ }^{\circ} \mathrm{C}$ in the case of LFP, has been decreased to $600{ }^{\circ} \mathrm{C}$ because the LMP is known to be damaged when heated at $\mathrm{T}>650{ }^{\circ} \mathrm{C}$. This decrease of the sintering temperature results in a carbon coat of the LFP layer that is less regular, but it is continuous as it can be seen in the TEM image in Figure 4b. In this process, we take advantage of the catalytic effect of Fe to coat the particle, since the carbon is deposited on the buffer LFP layer.

Figure 4. (a) Energy Dispersive X-ray Detector (EDX) spectra at three spots show that both $\mathrm{Mn}$ and $\mathrm{Fe}$ in the analyzed areas with $\mathrm{Mn}$ peak intensity higher than Fe's one. On average, the relative concentration $\mathrm{Mn}: \mathrm{Fe}$ is $2 / 3: 1 / 3$. ( $\mathrm{Cu}$ and $\mathrm{Si}$ are from the sample support); (b) Transmission Electron Microscope (TEM) image showing the continuous carbon coating deposited onto the LFP layer. (Reprinted with permission from [59]. Copyright 2012 Elsevier.)
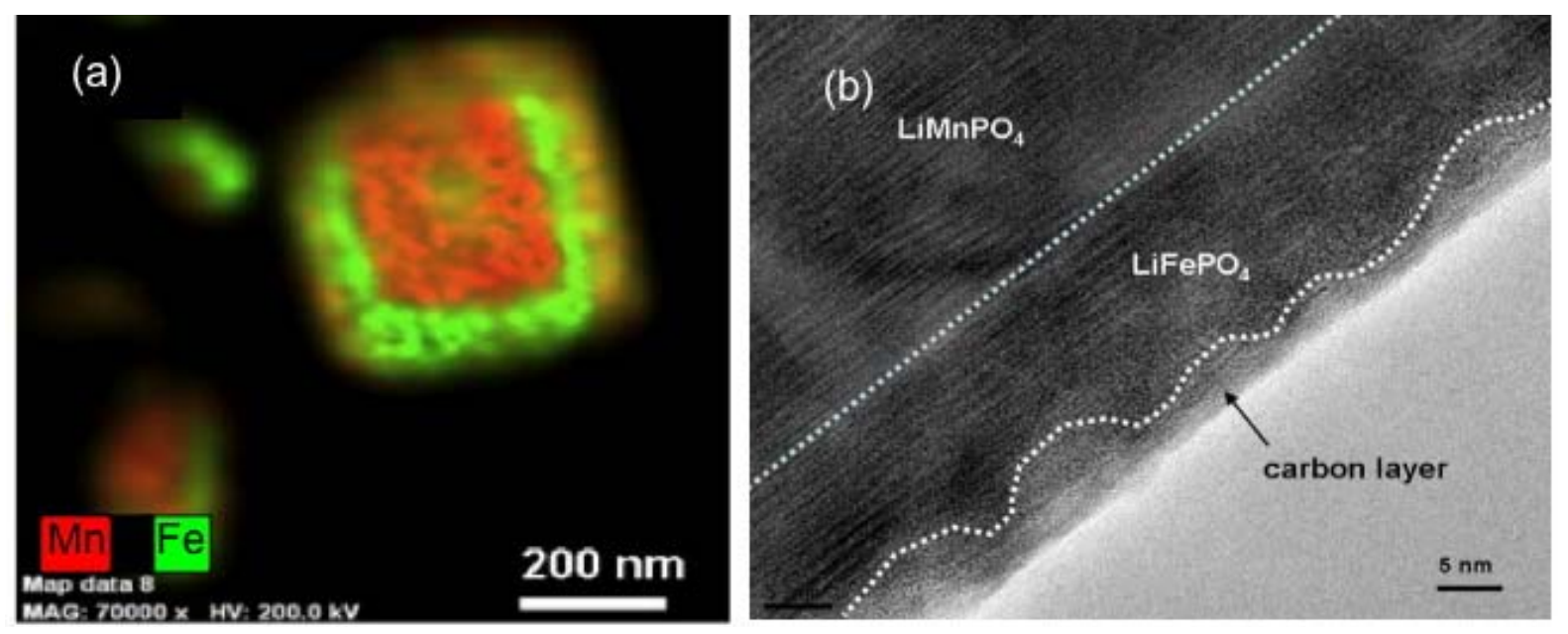

Moreover, the LFP layer is active and participates to the lithiation-delithiation process, so that it does not reduce the capacity. This participation is illustrated in Figure 5, which shows the variation of the potential with time for the first two cycles (same anode and same electrolyte as in the previous section). The current has been fixed to the value that would correspond to theoretical cycles at $\mathrm{C} / 24$ rate. The flat part corresponds to the limit of $4.5 \mathrm{~V}$ imposed to the potential to protect the electrolyte. The first plateau observed at $3.4 \mathrm{~V}$ is characteristic of the $\mathrm{Fe}^{2+} / \mathrm{Fe}^{3+}$ redox potential vs. Li in LFP. The 
next plateau at $4.0 \mathrm{~V}$ is characteristic of the $\mathrm{Mn}^{2+} / \mathrm{Mn}^{3+}$ potential in LMP, so that both components efficiently contribute to the electrochemical properties.

Figure 5. Voltage as a function of time in charge/discharge conditions corresponding to theoretical rate $\mathrm{C} / 24$ for the composite $\mathrm{C}-\mathrm{LiFePO}-\mathrm{LiMnPO}_{4}$ and $\mathrm{LiMn}_{2 / 3} \mathrm{Fe}_{1 / 3} \mathrm{PO}_{4}$ for comparison. (Reprinted with permission from [59]. Copyright 2012 Elsevier.)
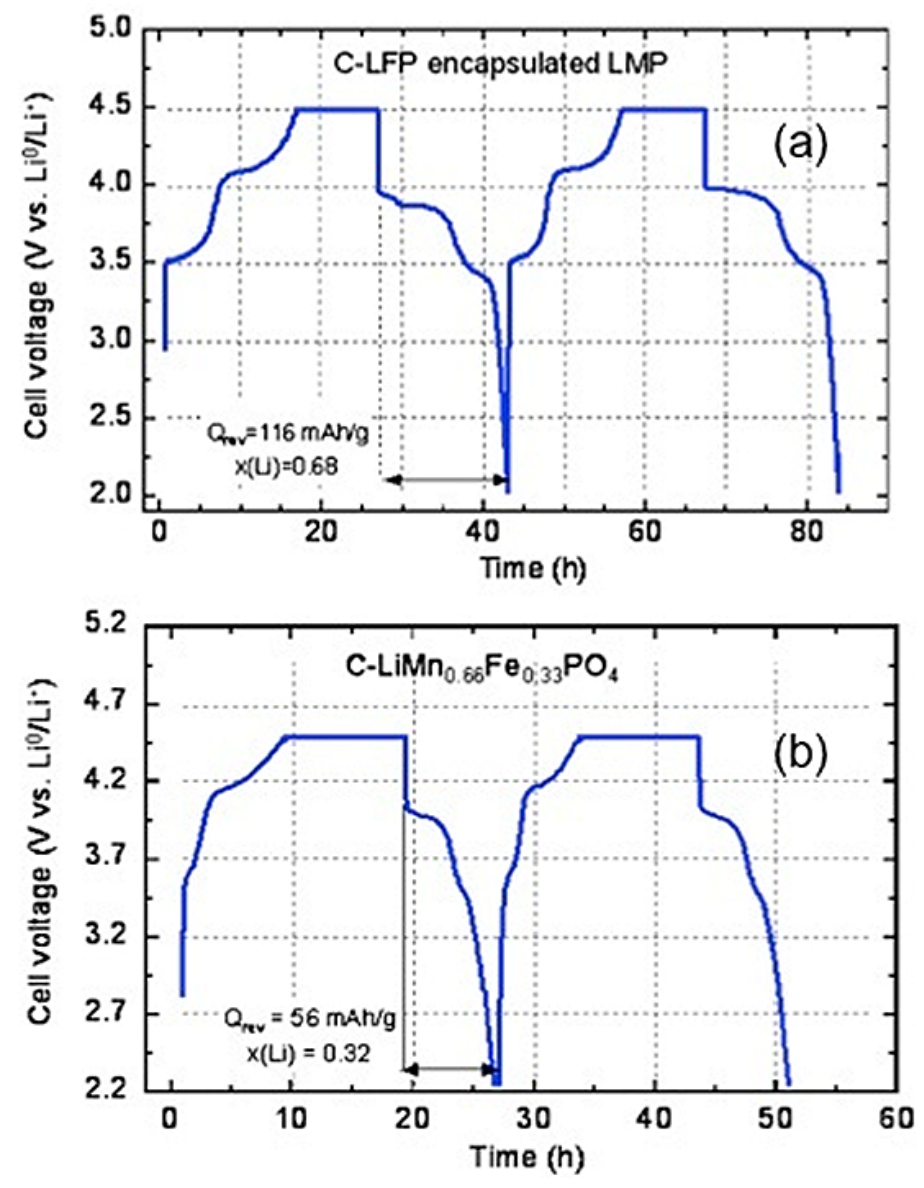

The Mn:Fe ratio for the multi-composite particles used to obtain the results displayed in Figures 4 and 5 is $2: 1$. The pertinence of synthesis of the multi-composite can thus be estimated by comparison of its electrochemical performance relative to that of the multi-ion solid solution with the same $\mathrm{Mn}$ :Fe ratio, i.e., $\mathrm{LiMn}_{2 / 3} \mathrm{Fe}_{1 / 3} \mathrm{PO}_{4}$. This solid-solution sample has been prepared following the same procedure to make sure that the size distribution of the particles is the same as in the composite samples. Since the addition of carbon among the precursors to obtain carbon-coated samples in a one-step synthesis process limits the growth of the particles during synthesis, thus reducing the size of the particles, the $\mathrm{LiMn}_{2 / 3} \mathrm{Fe}_{1 / 3} \mathrm{PO}_{4}$ have been prepared first, following the same synthesis process used to obtain the $\mathrm{LiMnPO}_{4}$ particles in the first synthesis step, and the carbon-coat of these particles is added only in a second synthesis step [59]. The analysis by SEM and TEM experiments have confirmed that the size distribution of the $\mathrm{C}-\mathrm{LiMn}_{2 / 3} \mathrm{Fe}_{1 / 3} \mathrm{PO}_{4}$ particles thus obtained is the same as that of the multi-composite $\mathrm{C}-\mathrm{LiFePO}$ - $\mathrm{LiMnPO}_{4}$ particles. The drawback is that the size of the particles is in the range 100-200 $\mathrm{nm}$, while the optimum size would be smaller than $100 \mathrm{~nm}$ to obtain capacities close to theoretical; but in this first study, we preferred a comparison between the multi-ionic synthesis route $\left(\mathrm{LiMn}_{2 / 3} \mathrm{Fe}_{1 / 3} \mathrm{PO}_{4}\right)$ and the multi-composite route $\left(\mathrm{C}-\mathrm{LiFePO}_{4}-\mathrm{LiMnPO}_{4}\right)$. The results obtained 
for $\mathrm{LiMn}_{2 / 3} \mathrm{Fe}_{1 / 3} \mathrm{PO}_{4}$ are also reported in Figure 5; they show that the multi-composite sample gives a definitely better performance. This improvement holds at any C-rate as can be seen in Figure 6 . Moreover, the multi-composite sample does not age upon cycling at the scale of 100 cycles explored in [59]. The synthesis of multi-composite systems is thus a promising route to increase the operating voltage to $4 \mathrm{~V}$.

Figure 6. Modified Peukert plot for the $\mathrm{C}-\mathrm{LiFePO}-\mathrm{LiMnPO}_{4}$ and $\mathrm{LiMn}_{2 / 3} \mathrm{Fe}_{1 / 3} \mathrm{PO}_{4}$ samples for comparison. (Reprinted with permission from [59]. Copyright 2012 Elsevier.)

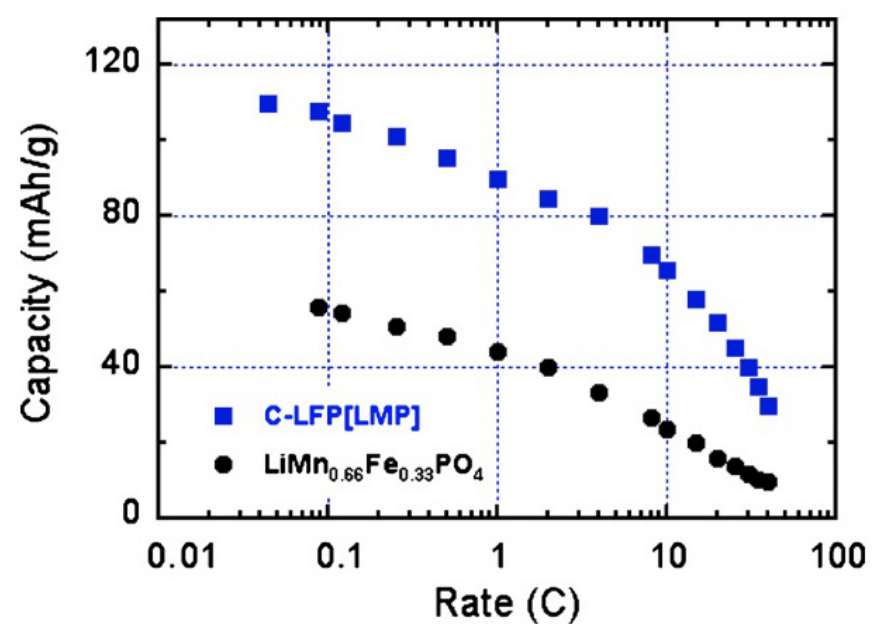

To increase even more the operating voltage, $\mathrm{Mn}$ must be replaced by Ni. However, the $\mathrm{LiNiPO}_{4}$ olivine has very poor electrochemical performance, and the efficiency of the redox reaction does not exceed $45 \%$ [60], so that we have to go back to the spinel family. Indeed, $\mathrm{LiMn}_{1.5} \mathrm{Ni}_{0.5} \mathrm{O}_{4}$ is more promising because of the attractive plateau at around $4.7 \mathrm{~V}$ vs. lithium $[61,62]$. Nevertheless, the Fermi energy is below the HOMO of the carbonate electrolyte, so that a passivating SEI layer is formed to obtain the reversible $\mathrm{Ni}(\mathrm{IV}) / \mathrm{Ni}(\mathrm{II})$ redox reaction $[63,64]$, leading to a degradation of the electrochemical performance [65]. In this case, the coating of the particles with $\mathrm{LiFePO}_{4}$ is expected to protect the surface of $\mathrm{LiMn}_{1.5} \mathrm{Ni}_{0.5} \mathrm{O}_{4}$ from reaction with the electrolyte. The multi-composite $\mathrm{LiMn}_{1.5} \mathrm{Ni}_{0.5} \mathrm{O}_{4}$ coated with $\mathrm{C}-\mathrm{LiFePO}_{4}$ has been synthesized with a novel mechano-fusion dry process [66]. The EDX maps of $\mathrm{P}$ (a) and $\mathrm{Fe}$ (b) elements for the $200 \mathrm{~nm}$-thick particles in Figure 7 show that the $\mathrm{C}-\mathrm{LiFePO}_{4}$ coat is uniform.

Figure 7. EDX maps of the $\mathrm{P}(\mathbf{a})$ and $\mathrm{Fe}(\mathbf{b})$ elements for the $\mathrm{C}-\mathrm{LiFePO}{ }_{4}$ coated $\mathrm{LiMn}_{1.5} \mathrm{Ni}_{0.5} \mathrm{O}_{4}$ multi-composite. (Reprinted with permission from [66]. Copyright 2012 Elsevier.)
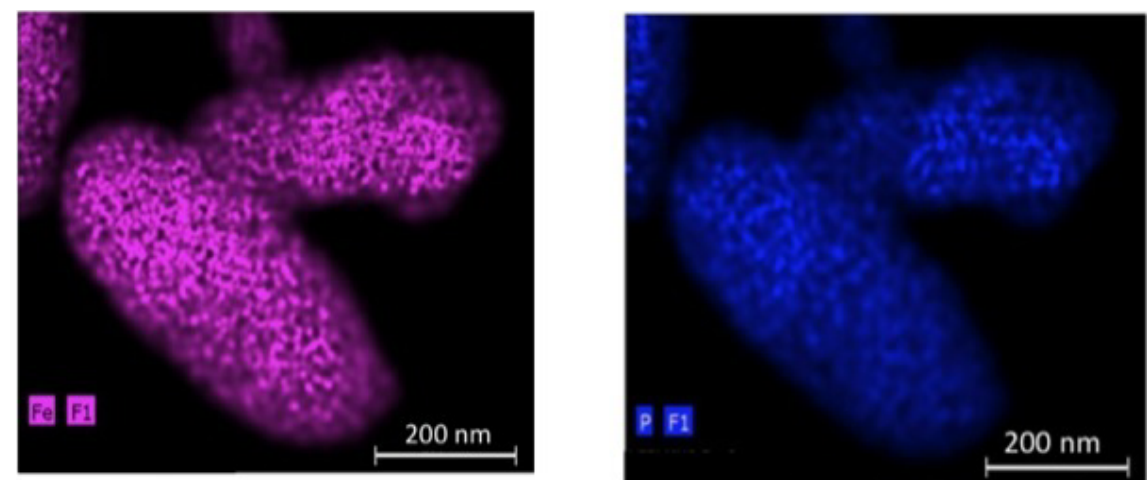
To test the electrochemical performance, a cell has been prepared with the same Li-anode and same electrolyte as in the prior sections. The cell has been cycled in the voltage range 3-4.9 V. At slow C-rate, the voltage profile in Figure 8 shows the plateau at $3.4 \mathrm{~V}$ characteristic of the $\mathrm{LiFePO}_{4}$ part, followed at higher potential by the contribution of the spinel part. As in the previous case, we have compared the electrochemical performance of the bare $\mathrm{LiMn}_{1.5} \mathrm{Ni}_{0.5} \mathrm{O}_{4}$ particles with that of the same particles after coating with $\mathrm{C}-\mathrm{LiFePO}_{4}$. As a result, taking into account that the fraction of the spinel part with respect to the olivine part in the multi-composite powder is in the ration $1 / 0.8$, we find that the capacity up to $10 \mathrm{C}$ in Figure 8 is just the sum of the spinel part and the olivine part, as expected. At higher C-rate, however, the capacity is much higher, as can be seen in the modified Peukert plot in Figure 9.

Figure 8. Discharge profiles of the $\mathrm{Li} / / \mathrm{C}-\mathrm{LiFePO}_{4}$-coated $\mathrm{LiMn}_{1.5} \mathrm{Ni}_{0.5} \mathrm{O}_{4}$ cell at different $\mathrm{C}$ rates. (Reprinted with permission from [66]. Copyright 2012 Elsevier.)

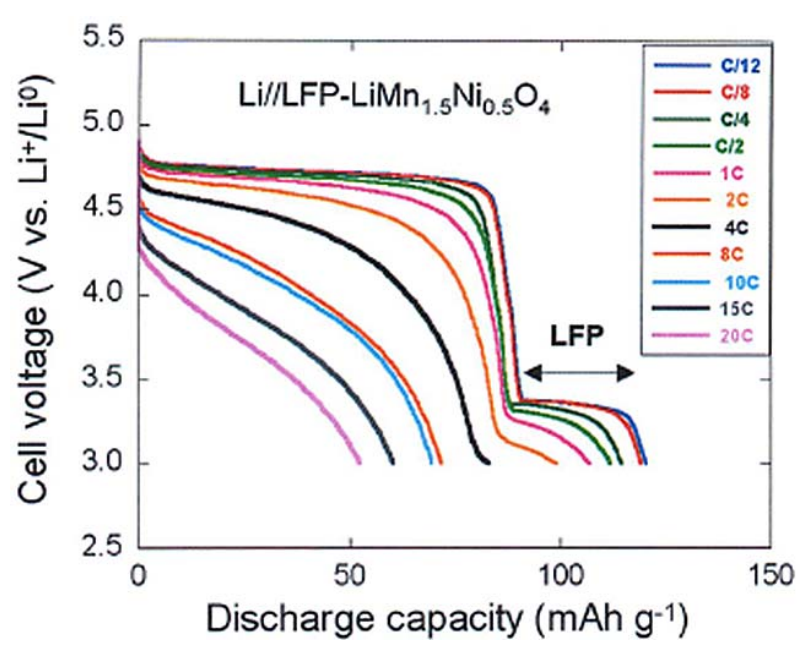

Figure 9. Modified Peukert plot of the $\mathrm{Li} / / \mathrm{C}$-LiFePO -coated and uncoated $\mathrm{LiMn}_{1.5} \mathrm{Ni}_{0.5} \mathrm{O}_{4}$ cells between 3.0 and 4.9 V. (Reprinted with permission from [66]. Copyright 2012 Elsevier.)

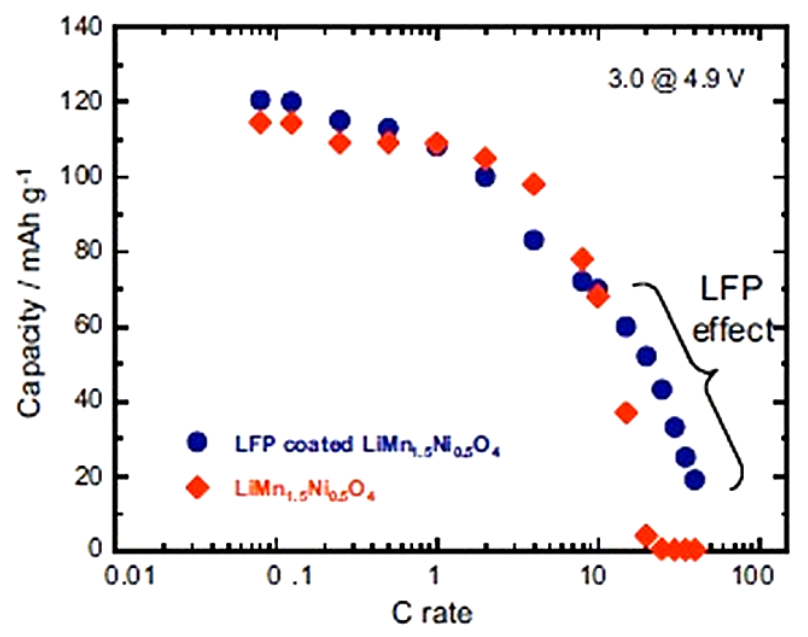

With respect to the capacity of uncoated LMN, the analysis [66] shows that the capacity of the spinel part has increased by $60 \%$ already at $15 \mathrm{C}$ and has been multiplied by the factor 13.3 at $20 \mathrm{C}$ after coating. We attribute this effect to the protection of the $\mathrm{C}-\mathrm{LiFePO}_{4}$ coat that has isolated the 
spinel part from the electrolyte, thus preventing the formation of a resistive SEI layer responsible for the poor performance of the bare LMN particles. This hypothesis is confirmed by the major improvement of the capacity retention upon cycling reported in Figure 10. Note that a simple improvement of the electronic conductivity of the multi-composite powder by a carbon coat of LFP may also contribute to an improvement of the capacity at high C-rate, but it cannot have any effect on the aging upon cycling. Figure 10 is thus the best evidence of the protective effect of the C-LFP against the reaction of the spinel with the electrolyte.

Figure 10. Cyclability of the $\mathrm{Li} / \mathrm{LiMn}_{1.5} \mathrm{Ni}_{0.5} \mathrm{O}_{4}$ and $\mathrm{Li} / \mathrm{LiFePO}$-coated $\mathrm{LiMn}_{1.5} \mathrm{Ni}_{0.5} \mathrm{O}_{4}$ cells at $1 \mathrm{C}$ between 3 and $4.9 \mathrm{~V}$. (Reprinted with permission from [66]. Copyright 2012 Elsevier.)

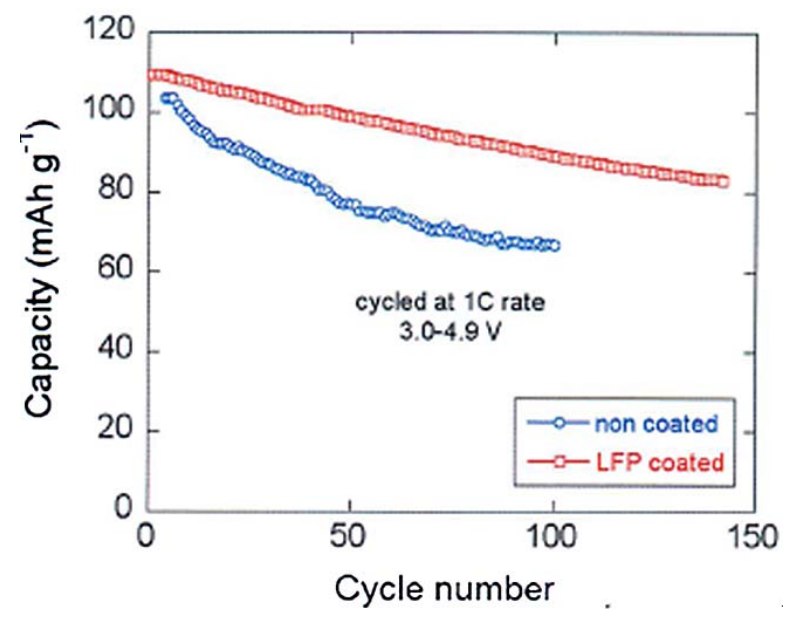

To increase even more the operational voltage, and to switch to the $5 \mathrm{~V}$-class of electrode materials, one has to consider cobalt compounds. Actually, it is possible to return to the olivine family because, while the electrochemical properties of $\mathrm{LiNiPO}_{4}$ are very poor as already mentioned, it is possible to lithiate and delithiate $\mathrm{LiCoPO}_{4}$ even though its capacity retention upon cycling is poor. Coating of $\mathrm{LiCoPO}_{4}$ by a nano-film of $\mathrm{LiFePO}_{4}$ has been obtained by a sol-gel process [67]. A similar improvement of the capacity retention upon cycling as the one reported in Figure 10 has been obtained in this case (see Figure 3 in [67]), which is again attributable to the protection of the LFP coat. Note that the LFP layer was not carbon-coated in this case, at least intentionally. It is possible that the particles have been unintentionally carbon-coated owing to the carbon present among the precursors, but it is impossible to know it since no detail on the choice of the precursors have been given in [67] and no characterization of the surface (by Raman spectroscopy for instance) has been done to check the presence of carbon, which is needed to optimize the electrochemical properties. In any case, coating the lamellar, spinel, and olivine compounds by C-LFP is always beneficial to the performance of the cathode elements; it improves the capacity, in particular at high C-rate, and protects the core particles from chemical reaction with the electrolyte.

\section{The $\mathrm{Li}_{4} \mathrm{Ti}_{5} \mathrm{O}_{12}$ Negative Electrode}

We have already mentioned in the introduction that the graphitic negative electrode is responsible for the aging (both calendar life and cycling life) of the battery and also for the limitation on charging rate and the discharge power of the LFP-based batteries. That is why efforts have been made recently 
to get rid of the graphite and replace it by LTO. This spinel material has several properties that have promoted it as an anode element. First, the change of volume upon lithiation and delithiation is negligible, thus avoiding the fatigue effects of the graphite particles. The absence of any resistive SEI layer is a second advantage. Third, the lithiation in LTO is also a two-phase system, allowing fast cooperative motion of the $\mathrm{Li}^{+}$ions as in the iron phosphate case. Therefore, this anode avoids the $\mathrm{Li}$ plating that is inevitable with graphite at high C-rate. The substitution of the graphite by $\mathrm{Li}_{4} \mathrm{Ti}_{5} \mathrm{O}_{12}$ has led recently to C-LFP//LTO batteries with excellent performance [68]. While the graphite anode limits the use of the battery typically to 3000 cycles and discharge rate to 6C, the C-LFP//LTO 18650-size cell delivers a capacity of $800 \mathrm{mAh}$, retains full capacity after 20,000 cycles performed at a charge rate 10C (6 min) with a discharge rate of $5 \mathrm{C}(12 \mathrm{~min})$, and retains $95 \%$ capacity after 30,000 cycles at a charge rate $15 \mathrm{C}(4 \mathrm{mn})$ and a discharge rate $5 \mathrm{C}$ at $100 \%$ depth of discharge (DOD) and 100\% state of charge (SOC) [68]. This performance is illustrated in Figure 11. Even better performances have been achieved by coating the LTO particles with carbon. The C-LFP//C-LTO 18650-size cells formed with particles of average size $90 \mathrm{~nm}$ for both electrodes retains more than $80 \%$ of rated capacity at $60 \mathrm{C}$ charge rate [69]. In addition, the temperature at any place inside the cell, measured by infrared camera, remains low. As an example, the thermal infrared images obtained at full charge and full discharge at a rate of $50 \mathrm{C}$ are reported in Figure 12. These images show that the maximum temperature reached under such conditions does not exceed $48.5^{\circ} \mathrm{C}$ at full charge, and $38.9{ }^{\circ} \mathrm{C}$ at full discharge. These results have been obtained with the commonly used electrolyte $1 \mathrm{~mol} \mathrm{~L}^{-1} \mathrm{LiPF}_{6}$ in ethylene and diethyl carbonates EC-DEC (1:1). This electrolyte, however, is sensitive to a raise of temperature. First, as $\mathrm{T}$ increases, $\mathrm{LiPF}_{6}$ degrades in the presence of organic solvents; the product of this decomposition, HF, induces acid dissolution of cathode-active materials [70,71]. Second, the organic solvents can decompose the SEI layer [72,73] and generate direct reactions between cathode-active materials and the electrolyte [74]. The consequence is a fast deterioration of the batteries at high temperature, and, in practice, is the reason why the electric cars must be equipped with a cooling system that keeps the temperature of the Li-ion batteries below $30{ }^{\circ} \mathrm{C}$ to avoid too fast aging. However, the substitution of graphite by LTO makes possible the use of other electrolytes and salts, more stable at higher temperature. The potential of the LFP//LTO is $1.9 \mathrm{~V}$. This low voltage reduces the energy density with respect to the $3.4 \mathrm{~V}$ obtained with graphite. However it has another advantage: it is small enough so that $\mathrm{LiPF}_{6}$ can be replaced by the much more stable lithium bis(trifluoromethanesulfonyl)imide $\left(\mathrm{LiN}\left(\mathrm{CF}_{3} \mathrm{SO}_{2}\right)_{2}\right.$, LiTFSI) salt without inducing corrosion on the aluminum collector. In particular, a major improvement has been achieved at any C-rate with the $0.5 \mathrm{~mol} \mathrm{~L}^{-1} \mathrm{LiTFSI}+1 \mathrm{~mol} \mathrm{~L}^{-1} \mathrm{LiBF}_{4}$ in EC- $\gamma$-butyrolactone $(\mathrm{GBL})$. At $60{ }^{\circ} \mathrm{C}$, the discharge capacity of a 2032-size coin LFP//LTO cell with this electrolyte remains larger than $120 \mathrm{mAh} \mathrm{g}^{-1}$ up to rate $10 \mathrm{C}$. At $40 \mathrm{C}$ rate, the capacity remains as high as $92 \mathrm{mAh} \mathrm{g}^{-1}$, while it drops to $20 \mathrm{mAh} \mathrm{g}^{-1}$ with $\mathrm{LiPF}_{6}$ in EC-DEC owing to the strong degradation of $\mathrm{LiPF}_{6}$ above $30{ }^{\circ} \mathrm{C}$. Therefore, this combination LFP with LTO can be used to increase significantly the operating temperature range of the battery. 
Figure 11. Cycle life of a $\mathrm{LiFePO}_{4} / \mathrm{EC}-\mathrm{DEC}-1 M \mathrm{LiPF}_{6} / \mathrm{Li}_{4} \mathrm{Ti}_{5} \mathrm{O}_{12} 18650$-cell. The cycle charge rate is $10 \mathrm{C}(6 \mathrm{~min})$ at $100 \%$ state of charge, the discharge rate is $5 \mathrm{C}(12 \mathrm{~min})$ at $100 \%$ depth of discharge during the test (Reprinted with permission from [68]. Copyright 2011 Elsevier).

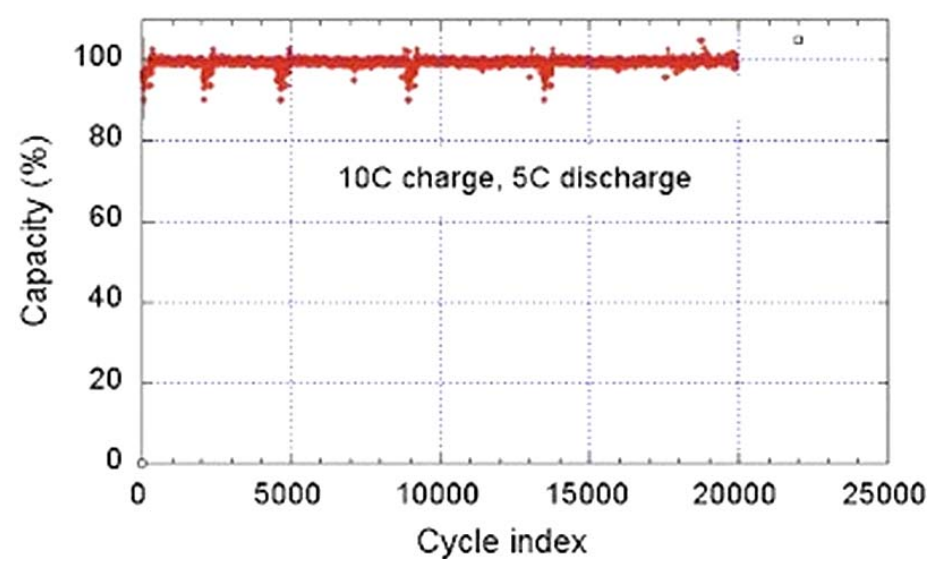

Figure 12. Thermal infrared image of the LTO//LFP "18650"-type cell recorded during charge at rate $50 \mathrm{C}$, at full charge $2.1 \mathrm{~V}$ (bottom), and total discharge at $1.0 \mathrm{~V}$ (top). The electrolyte is with $1 \mathrm{~mol} \mathrm{~L}^{-1} \mathrm{LiPF}_{6}$ in EC-DEC (1:1). (Reprinted with permission from [68]. Copyright 2011 Elsevier.)

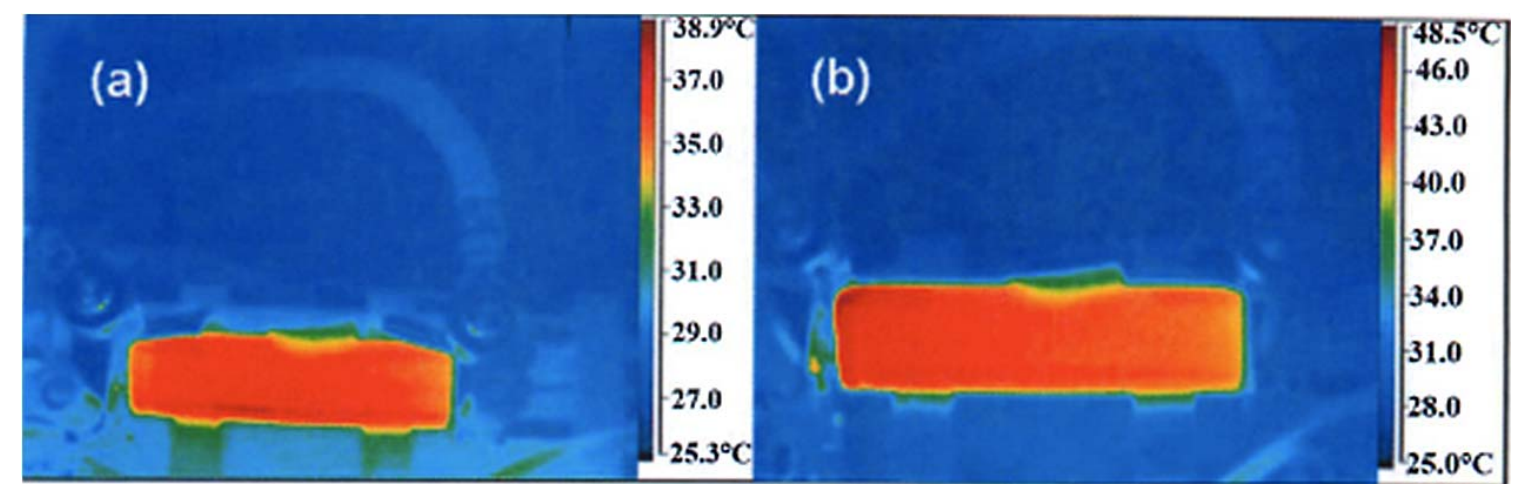

\section{Discussion}

The fact that the multi-composite $\mathrm{C}-\mathrm{LiFePO} / / / \mathrm{LiMnPO}_{4}$ has better electrochemical properties at any rate than $\mathrm{LiMn}_{y} \mathrm{Fe}_{1-y} \mathrm{PO}_{4}$ with the same proportion of $[\mathrm{Mn}] /[\mathrm{Fe}]$ illustrates the fact that the recent synthesis route of multi-composite cathode elements is more promising that the more classical attempt to synthesize multi-ion particles. To understand this effect, we note that the Jahn-Teller (JT) distortion associated to the presence of $\mathrm{Mn}^{3+}$ may induce $\mathrm{Mn}^{3+}$-rich inhomogeneities in the solid solution that distort the lattice locally to increase significantly the strain field evidenced in [75]. The resulting structural disorder may reduce the diffusivity of the $\mathrm{Li}^{+}$ions and that of the electrons to decrease the electrochemical performance. For the same reason, the structural disorder of the surface layer reduces the electrochemical performance of the lamellar compounds and of the olivine family as well. A second reason for the degradation of the electrochemical performance comes from the fact that the surface of the olivine is disordered in the absence of a carbon coat, which increases the resistance to $\mathrm{Li}^{+}$transfer across the electrolyte interface. A third reason has not been pointed out so far; the $\mathrm{Fe}^{3+}$ 
ions generated by delithiation of the surface layer upon exposure of the particles to moisture are in the high-spin state where the surface layer is well-crystallized, but in the low spin state where the surface layer is disordered (i.e., for uncoated $\mathrm{LiFePO}_{4}$ particles). Since $\mathrm{Fe}^{3+}$ in the low-spin state is significantly smaller, it will contribute to the structural disorder and thus to the degradation of the electrochemical properties. The thickness of the disordered surface layer (DSL) of as-grown, non-coated particles of both lamellar and olivine materials is small, typically $3 \mathrm{~nm}$, but the disorder inside this layer is very large so that it has sizeable effects, as shown in this review. It is, therefore, important to modify the surface layer so that it is well-crystallized, which can be done by heat treatment in presence of an organic compound.

The poor performance of multi-ion cathode elements is not limited to the case of $\mathrm{LiMn}_{y} \mathrm{Fe}_{1-y} \mathrm{PO}_{4}$; it extends to the other $\mathrm{LiMPO}_{4}$ members of the olivine family where $M$ is a mixture of $\mathrm{Fe}$ with other transition-metal ions. This is true not only for $\mathrm{LiNi}_{y} \mathrm{Fe}_{1-y} \mathrm{PO}_{4}$ [76], which is not surprising since low-spin $\mathrm{Ni}^{3+}$ is also a strong $\mathrm{JT}$ ion, but also for $\mathrm{LiCo}_{y} \mathrm{Fe}_{1-y} \mathrm{PO}_{4}$ [77]. In both cases, a partial substitution of $\mathrm{Fe}$ results in a decrease of the capacity and a poorer capacity retention. It is then not surprising that the same degradation in the performance is observed in presence of three $M$ elements [78-80], or even four $M$ elements [81] obtained by mixing $\mathrm{Fe}, \mathrm{Mn}, \mathrm{Ni}$ and Co ions. Indeed, one reason for the remarkable performance of $\mathrm{LiFePO}_{4}$ may also be due to the fact that the $\mathrm{Fe}^{2+}$ ion is not a strong Jahn-teller ion, and the $\mathrm{Fe}^{3+}$ ion in the delithiated material is not a Jahn-teller ion because it is everywhere in the high-spin state, including the surface if the particles are carbon-coated. Indeed, while we have shown in the previous sections that $\mathrm{C}-\mathrm{LiFePO}_{4}$ can deliver more than $160 \mathrm{mAh} \mathrm{g}^{-1}$ at low $\mathrm{C}$-rate, and can be charged/discharged at $40 \mathrm{C}$ rate without aging over 20,000 cycles, no sample with Fe partly substituted by one or more transition element has ever been able to approach this performance. For these different reasons, we believe that the new route to multi-composite systems is much more promising than the multi-ion synthesis.

If the $\mathrm{LiFePO}_{4}$-coating of $\mathrm{LiMnPO}_{4}$ has been successful, it will also be a fortiori for $\mathrm{LiFePO}_{4}$-coating of $\mathrm{LiMn}_{y} \mathrm{Fe}_{1-y} \mathrm{PO}_{4}$ for any composition $y$ of the solid solution. Actually, the recipe has already been used for $y=0.88$ with results similar to expectation [82]. This composition, however, should not be the best, since the best electrochemical performance on these alloys has been obtained for $y<0.8$. The whole series of $\mathrm{LiFePO}_{4}$-coated $\mathrm{LiMn}_{y} \mathrm{Fe}_{1-y} \mathrm{PO}_{4}$ has yet to be explored in the most promising range of compositions $0.5<y<0.8$. The $\mathrm{LiFePO}_{4}$ coating also works successfully on other members of the family, such as $\mathrm{LiCoPO}_{4}$ [67]. $\mathrm{LiFePO}_{4}$ can be used to coat other cathode particles that do not belong to the olivine family. Such a coating led to a remarkable improvement of the electrochemical performance of lamellar compounds like $\mathrm{LiCoO}_{2}$ [51] and $\mathrm{LiNi}_{0.5} \mathrm{Co}_{0.2} \mathrm{Mn}_{0.3} \mathrm{O}_{2}$ [83], and more recently of the spinel $\mathrm{LiMn}_{1.5} \mathrm{Ni}_{0.5} \mathrm{O}_{4}$ [66]. The improvement of the electrochemical properties is linked to the remarkable stability of $\mathrm{LiFePO}_{4}$, which supports high voltage up to $5 \mathrm{~V}$ even though the $\mathrm{Fe}^{2+} / \mathrm{Fe}^{3+}$ potential vs. $\mathrm{Li}^{+} / \mathrm{Li}$ is $3.4 \mathrm{~V}$. Moreover, the $\mathrm{LiFePO}_{4}$ layer participates in the electrochemical process and thus does not decrease the energy density, in contrast to other coats that have been tried in the past. Next, nano-particles of LFP can be lithiated and delithiated very rapidly $[68,69]$, actually faster than the other compounds of the core, so that the LFP layer naturally improves the electrochemical performance at high C-rate. Moreover, as we has shown in the case of C-LFP-MN, the electrochemical performance of the LMN core at high C-rate is improved by the C-LFP coat with respect to the same LMN particles before coating. This remarkable result is because 
the $\mathrm{LiFePO}_{4}$ coat protects the core region against reaction with the electrolyte, so that any SEI layer is formed at the surface of the LFP and not at the surface of the more reactive LMN. This example, like that of LFP-coated $\mathrm{LiCoPO}_{4}$, gives evidence of a major step forward with the multi-composite electrodes toward the goal of obtaining operational $5 \mathrm{~V}$-batteries. Another beneficial effect of the $\mathrm{LiFePO}_{4}$ coat comes from the fact that the oxygen pressure at equilibrium increases sharply with redox potential above $3.5 \mathrm{~V}$ [84]. Therefore, any attempt to increase the voltage will also increase the risk of a loss of oxygen from the cathode element. When such a loss occurs with graphite as the negative electrode, the oxygen liberated from the positive electrode comes in contact with the anodic carbon with which it will react to form $\mathrm{CO}_{2}$. Since this reaction is exothermic, it can generate thermal runaway of the battery. The $\mathrm{LiFePO}_{4}$ shell of the multi-composite particles has thus another major advantage: by preventing the oxygen from migrating outside the core region, it will insure the thermal stability of the $4 \mathrm{~V}$ and $5 \mathrm{~V}$ battery. Of course, there are still problems to be solved before we can have a safe and performing $5 \mathrm{~V}$ battery, like the stability of the electrolyte. However, in this area too progress is currently being made by using tetramethylene sulfone, which is stable up to $5.8 \mathrm{~V}$, for instance $[85,86]$. Therefore, the possibility to increase the voltage of Li-ion batteries in the near future does not seem out of reach.

The energy density is not only limited by the operating voltage of the battery, but also by the fact that one Li per chemical formula can be extracted from the cathode materials that have been reviewed in the present work. Therefore, a lot of efforts are currently being made to find a new chemistry that would make possible the extraction of two $\mathrm{Li}^{+}$ions instead of one. A solution that is envisioned is the replacement of the phosphorous with silicon. Two materials from a new family of transition-metal silicate, namely $\mathrm{Li}_{2} \mathrm{MnSiO}_{4}$ and $\mathrm{Li}_{2} \mathrm{FeSiO}_{4}$, have been successfully prepared and preliminary tested for positive electrode materials [87-91]. These materials are even more insulating than the $\mathrm{LiFe}(\mathrm{Mn})$ olivines, but again, the same solution has been found to overcome the problem, namely carbon coating, not only of the end members, but also of the solid solution $\mathrm{Li}_{2} \mathrm{Fe}_{0.5} \mathrm{Mn}_{0.5} \mathrm{SiO}_{4}$ [92]. If the two $\mathrm{Li}^{+}$ions might be extracted reversibly, the theoretical capacity would be raised to about $333 \mathrm{mAh} \mathrm{g}^{-1}$. Unfortunately reversible extraction of two lithium ions has not been achieved owing to the structural instability of these transition-metal silicates and the subsequent amorphization that has been observed during studies of the charge/discharge operation [93,94]. To overcome this problem, the only possibility is again to decrease the size of the particles to the nano-range so that the range of the strain field is larger than the size of the particles, in which case we can hope that the lattice distortion can be accommodated not locally, but by the particle as a whole. Indeed, in a recent work [95] the authors have succeeded in preparing ultrathin nanosheets of $\mathrm{Li}_{2}(\mathrm{Fe}, \mathrm{Mn}) \mathrm{SiO}_{4}$ that has a capacity close to theoretical with a good capacity retention over 20 cycles. This is a remarkable example of the improvements that the recent nanosheet technology can bring to the field of the Li-ion batteries since the nanosheets combine two essential properties: a large surface area, which is desired to increase the surface contact with the electrolyte, and nanoscopic thickness. Of course, the stability over 20 cycles does not make the material eligible for its use in a Li-ion battery since a reversible two-lithium-ion capacity with stable cyclic performance requires a cathode that is stable toward structural and volume changes during thousands of cycles. Nevertheless, this result is remarkable if we note that it was not possible to make more than one or two cycles before. It is then a motivation to pursue the research in this field, and it illustrates that the nano-science and technology raise the hope for the increase in the 
energy density of Li-ion batteries in the future. Nevertheless, the structural instability mentioned for these compounds is associated to the very large variation of volume in the lithiation and the delithiation process, so that low C-rates seem mandatory to avoid cracks and deterioration of the compounds. Therefore, it is doubtful that the silicates will be able to combine high energy density and high power. We recover the same conflict that we have met with the choice between the $\mathrm{Li}_{4} \mathrm{Ti}_{5} \mathrm{O}_{12}$ and the graphite anode: we have to make a choice between more energy or more power.

\section{Conclusions}

Recent progress in the reduction in size of the active particles of the electrodes below $100 \mathrm{~nm}$ has increased the surface contact with the electrolytes, thus improving the power density of the Li-ion batteries. At the same time, however, the surface-over-volume ratio increases, so that the surface layer, as well as SEI effects, becomes increasingly important. Recent improvements for the positive electrodes have been obtained by well-crystallized surface layer of both lamellar compounds and olivine compounds. For the negative electrode, $\mathrm{Li}_{4} \mathrm{Ti}_{5} \mathrm{O}_{12}$ gives outstanding results when combined with the $\mathrm{LiFePO}_{4}$ positive electrode since this battery does not age at the scale of 20,000 cycles, even at very high $\mathrm{C}$-rates. The only drawback of the substitution of graphite by $\mathrm{Li}_{4} \mathrm{Ti}_{5} \mathrm{O}_{12}$ is a loss of energy density.

The energy density, however, can be increased by using the remarkable thermal stability of $\mathrm{LiFePO}_{4}$ to coat particles working at higher operating voltage. Such multi-composite materials have improved the performance with respect to multi-ion samples of the same overall composition. Another interest of the $\mathrm{LiFePO}_{4}$ coating is that it protects the inner core of the particles from contact and reaction with the electrolyte, which not only prevents the formation of a resistive SEI layer, but also increases the safety of the Li-ion batteries. In particular, the multi-composite particles open the route towards the $5 \mathrm{~V}$ operating Li-ion batteries, and the results on the $\mathrm{LiFePO}_{4}$-coated $\mathrm{LiMn}_{1.5} \mathrm{Ni}_{0.5} \mathrm{O}_{4}$ are encouraging.

Another attempt to increase the energy density is to pursue research into new chemistry to obtain cathode elements with more than one Li-ion per unit cell. The progress in nanoscience to prepare silicates particles of few $\mathrm{nm}$ in size only is encouraging, but it also suggests that the Li-ion batteries will be still confronted in the near future to the choice between more energy density and more power density. The solution might be the synthesis of multi-composite cathode particles with $\mathrm{C}$ - $\mathrm{LiFePO}_{4}$ shell, which allow for more energy by increasing the operating voltage, combined with the $\mathrm{Li}_{4} \mathrm{Ti}_{5} \mathrm{O}_{12}$ anode that allows for much higher power densities than graphite.

\section{References}

1. Nagaura, T.; Tozawa, K. Lithium ion rechargeable battery. Prog. Batter. Sol. Cells 1990, 9, 209-211.

2. Bang, H.J.; Joachin, H.; Yang, H.; Amine, K.; Prakash, J. Contribution of the structural changes of $\mathrm{LiNi}_{0.8} \mathrm{Co}_{0.15} \mathrm{Al}_{0.05} \mathrm{O}_{2}$ cathodes on the exothermic reactions in $\mathrm{Li}$-ion cells. J. Electrochem. Soc. 2006, 153, A731-A737. 
3. Zaghib, K.; Dubé, J.; Dallaire, A.; Galoustov, K.; Guerfi, A.; Ramanathan, M.; Benmayza, A.; Prakash, J.; Mauger, A.; Julien, C.M. Enhanced thermal safety and high power performance of carbon-coated $\mathrm{LiFePO}_{4}$ olivine cathode for Li-ion batteries. J. Power Sources 2012, 219, 36-44.

4. Ohzuku, T.; Makimura, Y. Layered lithium insertion material of $\mathrm{LiCo}_{1 / 3} \mathrm{Ni}_{1 / 3} \mathrm{Mn}_{1 / 3} \mathrm{O}_{2}$ for lithium-ion batteries. Chem. Lett. 2001, 30, 642-643.

5. Yabuuchi, N.; Ohzuku, T. Novel lithium insertion material of $\mathrm{LiCo}_{1 / 3} \mathrm{Ni}_{1 / 3} \mathrm{Mn}_{1 / 3} \mathrm{O}_{2}$ for advanced lithium-ion batteries. J. Power Sources 2003, 119-121, 171-174.

6. Mauger, A.; Gendron, F.; Julien, C.M. Magnetic properties of $\mathrm{Li}_{x} \mathrm{Ni}_{y} \mathrm{Mn}_{y} \mathrm{Co}_{1-2 y} \mathrm{O}_{2}(0.2 \leq 1-2 y \leq 0.5$, $0 \leq x \leq 1)$. J. Alloy. Compds. 2012, 520, 42-51.

7. Zhang, X.; Jiang, W.J.; Mauger, A.; Gendron, F.; Julien, C.M.; Qilu, R. Minimization of the cation mixing in $\mathrm{Li}_{1+x}(\mathrm{NMC})_{1-x} \mathrm{O}_{2}$ as cathode material. J. Power Sources 2010, 195, 1292-1301.

8. Padhi, A.K.; Nanjundaswamy, K.S.; Goodenough, J.B. Phospho-olivines as positive-electrode materials for rechargeable lithium batteries. J. Electrochem. Soc. 1997, 144, 1188-1194.

9. Ravet, N.; Chouinard, Y.; Magnan, J.F.; Besner, S.; Gauthier, M.; Armand, M. Electroactivity of natural and synthetic triphylite. J. Power Sources 2001, 97-98, 503-507.

10. Ait-Salah, A.; Mauger, A.; Julien, C.M.; Gendron, F. Nano-sized impurity phases in relation to the mode of preparation of $\mathrm{LiFePO}_{4}$. Mater. Sci. Eng. B 2006, 129, 232-244.

11. Julien, C.M.; Zaghib, K.; Mauger, A.; Groult, H. Enhanced electrochemical properties of $\mathrm{LiFePO}_{4}$ as positive electrode of Li-ion batteries for HEV application. Adv. Chem. Eng. Sci. 2012, 2, 321-329.

12. Zaghib, K.; Mauger, A.; Goodenough, J.B.; Gendron, F.; Julien, C.M. Positive electrode: Lithium iron phosphate. In Encyclopedia of Electrochemical Power Sources; Garche, J., Ed.; Elsevier Science Ed.: Amsterdam, the Netherland, 2009; Volume 5, pp. 264-296.

13. Julien, C.M.; Mauger, A.; Zaghib, K. Surface effects on electrochemical properties of nano-sized $\mathrm{LiFePO}_{4}$. J. Mater. Chem. 2011, 21, 9955-9968.

14. Zaghib, K.; Mauger, A.; Julien, C.M. Design and properties of $\mathrm{LiFePO}_{4}$ nano-materials for high power applications. In Nanotechnology for Lithium-ion Batteries; Abu-Lebdeh, Y., Davidson, I., Eds.; Springer: New York, NY, USA, 2012; pp. 179-220.

15. Rissouli, K.; Benkhouja, K.; Ramos-Barrado, J.R.; Julien, C.M. Electrical conductivity in lithium orthophosphates. Mater. Sci. Eng. B 2003, 98, 185-189.

16. Choi, D.; Wang, D.; Bae, I.-T.; Xiao, J.; Nie, Z.; Wang, W.; Viswanathan, V.V.; Lee, Y.J.; Zhang, J.-G.; Graff, G.L.; Yang, Z.; Liu, J. Nanoplate grown via solid-state reaction in molten hydrocarbon for Li-ion battery cathode. Nano Lett. 2010, 10, 2799-2805.

17. Wang, D.; Buqa, H.; Crouzet, M.; Deghenghi, G.; Drezen, T.; Exnar, I.; Kwon, N.-H.; Miners, J.H.; Poletto, L.; Grätzel, M. High performance of nano-structured $\mathrm{LiMnPO}_{4}$ synthesized via a polyol method. J. Power Sources 2009, 189, 624-628.

18. Martha, S.K.; Markovski, B.; Grinblat, J.; Gofer, Y.; Haik, O.; Zinigrad, E.; Aurbach, D.; Drezen, T.; Wang, D.; Deghenghi, G.; Exnar, I. $\mathrm{LiMnPO}_{4}$ as an advanced cathode material for rechargeable lithium batteries. J. Electrochem. Soc. 2009, 156, A541-A552.

19. Oh, S.-M.; Oh, S.-W.; Yoon, C.-S.; Scrosati, B.; Amine, K.; Sun, Y.-K. High-performance carbon-LiMnPO 4 nanocomposite cathode for lithium batteries. Adv. Funct. Mater. 2010, 20, 3260-3265. 
20. Bakenov, Z.; Tanigushi, I. $\mathrm{LiMg}_{x} \mathrm{Mn}_{1-x} \mathrm{PO}_{4} / \mathrm{C}$ cathodes for lithium batteries prepared by a combination of spray pyrolysis with wet ball milling. J. Electrochem. Soc. 2010, 157, A430-A436.

21. Ravet, N.; Gauthier, M.; Zaghib, K.; Mauger, A.; Goodenough, J.B.; Gendron, F.; Julien, C.M. Mechanism of the $\mathrm{Fe}^{3+}$ reduction at low temperature for the $\mathrm{LiFePO}_{4}$ synthesis from polymeric precursor. Chem. Mater. 2007, 19, 2595-2602.

22. Trudeau, M.L.; Laul, D.; Veillette, R.; Serventi, A.M.; Zaghib, K.; Mauger, A.; Julien, C.M. In situ high resolution transmission electron microscopy synthesis observation of nanostructured carbon-coated $\mathrm{LiFePO}_{4}$. J. Power Sources 2011, 196, 7383-7394.

23. Bakenov, Z.; Taniguchi, I. Physical and electronic properties of $\mathrm{LiMnPO}_{4} / \mathrm{C}$ composite cathode prepared with different conductive carbons. J. Power Sources 2010, 195, 7445-7451.

24. Kim, T.-H.; Park, H.-S.; Lee, S.-Y.; Song, H.-K. Restricted growth of $\mathrm{LiMnPO}_{4}$ nanoparticles evolved from a precursor seed. J. Power Sources 2012, 210, 1-6.

25. Oh, S.-M.; Jung, H.-G.; Yoon, C.S.; Myung, S.-T.; Chen, Z.; Amine, K.; Sun, Y.-K. Enhanced electrochemical performance of carbon- $\mathrm{LiMn}_{1-x} \mathrm{Fe}_{x} \mathrm{PO}_{4}$ nanocomposite cathode for lithium-ion batteries. J. Power Sources 2011, 196, 6924-6928.

26. Amine, K.; Tukamoto, H.; Yasuda, H.; Fujita, Y. Preparation and electrochemical investigation of $\mathrm{LiMn}_{2-x} \mathrm{Me}_{x} \mathrm{O}_{4}(\mathrm{Me}: \mathrm{Ni}, \mathrm{Fe}$ and $x=0.5,1)$ cathode materials for secondary batteries. J. Power Sources 1997, 68, 604-608.

27. Zhong, Q.; Bonakdarpour, A.; Zhang, M.; Gao, Y.; Dahn, J.R. Synthesis and electrochemistry of $\mathrm{LiNi}_{x} \mathrm{Mn}_{2-x} \mathrm{O}_{4}$. J. Electrochem. Soc. 1997, 144, 205-213.

28. Liu, J.; Manthiram, A. Understanding the improvement in the electrochemical properties of surface modified $5 \mathrm{~V} \mathrm{LiMn}{ }_{1.42} \mathrm{Ni}_{0.42} \mathrm{Co}_{0.16} \mathrm{O}_{4}$ spinel cathodes in lithium-ion cells. Chem. Mater. 2009, 21, 1695-1707.

29. Zaghib, K.; Charest, P.; Dontigny, M.; Guerfi, A.; Lagacé, M.; Mauger, A.; Kopek, M.; Julien, C.M. $\mathrm{LiFePO}_{4}$ : From molten ingot to nanoparticles with high-rate performance in Li-ion batteries. J. Power Sources 2010, 195, 8280-8288.

30. Brochu, F.; Guerfi, A.; Trottier, J.; Kopec, M.; Mauger, A.; Groult, H.; Julien, C.M.; Zaghib, K. Structure and electrochemistry of scaling nano $\mathrm{C}-\mathrm{LiFePO}_{4}$ synthesized y hydrothermal route: Complexing agent effect. J. Power Sources 2012, 214, 1-6.

31. Garcia, R.E.; Chiang, Y.-M.; Carter, W.C.; Limthongkul, P.; Bishop, C.M. Microstructural modeling and design of rechargeable lithium-ion batteries. J. Electrochem. Soc. 2005, 152, A255-A263.

32. Zhao, K.; Pharr, M.; Vlassak, J.J.; Suo, Z. Fracture of electrodes in lithium-ion batteries caused by fast charging. J. Appl. Phys. 2010, 108, 073517:1-073517:6.

33. Renganathan, S.; Sikha, G.; Santhanagopalan, S.; White, R.E. Theoretical analysis of stresses in a lithium-ion cell. J. Electochem. Soc. 2010, 157, A155-A163.

34. Vetter, J.; Novak, P.; Wagner, M.R.; Veit, C.; Möller, K.-C.; Besenhard, J.O.; Winter, M.; Wohlfahrt-Mehrens, M.; Vogler, C.; Hammouche, A. Ageing mechanisms in lithium-ion batteries. J. Power Sources 2005, 147, 269-281.

35. Broussely, M.; Biensan, P.; Bonhomme, F.; Blanchard, P.; Herreyre, S.; Nechev, K.; Staniewicz, R.J. Main aging mechanisms in Li-ion batteries. J. Power Sources 2005, 146, 90-96. 
36. Lu, W.; Lopez, C.M.; Liu, N.; Vaughey, J.T.; Jansen, A.; Dees, D.W. Overcharge effect on morphology and structure of carbon electrodes for lithium-ion batteries. J. Electrochem. Soc. 2012, 159, A566-A570.

37. Downie, L.E.; Chevrier, V.L.; Dahn, J.R.; Krause, L.J. In situ detection of lithium plating on graphite electrodes using electrochemical microcalorimetry. In Proceeding of the 222th ECS Meeting, Honolulu, HI, USA, 7-12 October 2012.

38. Ferg, E.; Gummow, R.J.; de Kock, A.; Thackeray, M.M. Spinel anodes for lithium-ion batteries. J. Electrochem Soc. 1994, 141, L147-L150.

39. Ohzuku, T.; Ueda, A.; Yamamoto, N. Zero-strain insertion material of $\mathrm{Li}\left[\mathrm{Li}_{1 / 3} \mathrm{~T}_{5 / 3}\right] \mathrm{O}_{4}$ for rechargeable lithium cells. J. Electrochem. Soc. 1995, 142, 1431-1435.

40. Thackeray, M.M. Lithiated Oxides for Lithium-Ion Batteries. In Rechargeable Lithium and Lithium-Ion Batteries; Megahed, S., Barnett, B.M., Xie, L., Eds.; The Electrochem. Soc. Proc. Series; ECS: Pennington, NJ, USA, 1995; p. 233.

41. Ait-Salah, A.; Mauger, A.; Zaghib, K.; Goodenough, J.B.; Ravet, N.; Gendron, F.; Julien, C.M. Reduction of $\mathrm{Fe}^{3+}$ impurities in $\mathrm{LiFePO}_{4}$ from pyrolysis of organic precursor used for carbon deposition. J. Electrochem. Soc. 2006, 153, A1692-A1701.

42. Shi, S.J.; Tu, J.P.; Mai, Y.J.; Zhang, Y.Q.; Gu, C.D.; Wang, X.L. Effect of carbon coating on electrochemical performance of $\mathrm{Li}_{1.048} \mathrm{Mn}_{0.381} \mathrm{Ni}_{0.286} \mathrm{Co}_{0.286} \mathrm{O}_{2}$ cathode material for lithium-ion batteries. Electrochim. Acta 2012, 63, 112-117.

43. Li, D.; Kato, Y.; Kobayakawa, K.; Noguchi, H.; Sato, Y. Preparation and electrochemical characteristics of $\mathrm{LiNi}_{1 / 3} \mathrm{Mn}_{1 / 3} \mathrm{Co}_{1 / 3} \mathrm{O}_{2}$ coated with metal oxides coating. J. Power Sources 2006, 160, 1342-1348.

44. Aurbach, D.; Gamolsky, K.; Markovsky, B.; Salitra, G.; Gofer, Y.; Heider, U.; Oesten, R.; Schmidt, M. The study of surface phenomena related to the electrochemical intercalation into $\mathrm{Li}_{x} M \mathrm{O}_{y}$ host materials $(M=\mathrm{Ni}, \mathrm{Mn})$. J. Electrochem. Soc. 2000, 147, 1322-1331.

45. Kannan, A.M.; Rabenberg, L.; Manthiram, A. High capacity surface-modified $\mathrm{LiCoO}_{2}$ cathodes for lithium-ion batteries. Electrochem. Solid State Lett. 2003, 6, A16-A18.

46. Oh, S.; Lee, J.K.; Byun, D.; Cho, W.; Cho, B.W. Effect of $\mathrm{Al}_{2} \mathrm{O}_{3}$ coating on electrochemical performance of $\mathrm{LiCoO}_{2}$ as cathode materials for secondary lithium batteries. J. Power Sources 2004, 132, 249-255.

47. Kweon, H.-J.; Park, J.J.; Seo, J.W.; Kim, G.B.; Jung, B.H.; Lim, H.S. Effects of metal oxide coatings on the thermal stability and electrochemical performance of $\mathrm{LiCoO}_{2}$ in a Li-ion cell. $J$. Power Sources 2004, 126, 156-162.

48. Chung, K.Y.; Yoon, W.-S.; Lee, H.S.; McBreen, J.; Yang, X.-Q.; Oh, S.H.; Ryu, W.H.; Lee, J.L.; Cho, W.L.; Cho, B.W. In situ XRD studies of the structural changes of $\mathrm{ZrO}_{2}$-coated $\mathrm{LiCoO}_{2}$ during cycling and their effects on capacity retention in lithium batteries. J. Power Sources 2006, 163, 185-190.

49. Chen, Z.; Dahn, J.R. Effect of a $\mathrm{ZrO}_{2}$ coating on the structure and electrochemistry of $\mathrm{Li}_{x} \mathrm{CoO}_{2}$ when cycled to 4.5 V. Electrochem. Solid-State Lett. 2002, 5, A213-A216.

50. Li, G.; Yang, Z.; Yang, W. Effect of $\mathrm{FePO}_{4}$ coating on electrochemical and safety performance of $\mathrm{LiCoO}_{2}$ as cathode material for Li-ion batteries. J. Power Sources 2008, 183, 741-748. 
51. Wang, H.; Zhang, W.-D.; Zhu, L.-Y.; Chen, M.-C. Effect of $\mathrm{LiFePO}_{4}$ coating on electrochemical performance of $\mathrm{LiCoO}_{2}$ at high temperature. Solid State Ion. 2007, 178, 131-136.

52. Yi, T.-F.; Shu, J.; Yue, C.-B.; Zhu, X.-D.; Zhou, A.-N.; Zhu, Y.-R.; Zhu, R.-S. Enhanced cycling stability of micro-sized $\mathrm{LiCoO}_{2}$ cathode by $\mathrm{Li}_{4} \mathrm{Ti}_{5} \mathrm{O}_{12}$ coating for lithium-ion battery. Mater. Res. Bull. 2010, 45, 456-459.

53. Kim, H.-S.; Kim, Y.; Kim, S.-I.; Martin, S.W. Enhanced electrochemical properties of $\mathrm{LiNi}_{1 / 3} \mathrm{Co}_{1 / 3} \mathrm{Mn}_{1 / 3} \mathrm{O}_{2}$ cathode material by coating with $\mathrm{LiAlO}_{2}$ nanoparticles. J. Power Sources 2006, 161, 623-627.

54. Kim, Y.; Kim, H.-S.; Martin, S.W. Synthesis and electrochemical characteristics of $\mathrm{Al}_{2} \mathrm{O}_{3}$-coated $\mathrm{LiNi}_{1 / 3} \mathrm{Co}_{1 / 3} \mathrm{Mn}_{1 / 3} \mathrm{O}_{2}$ cathode materials for lithium-ion batteries. Electrochim. Acta 2006, 52, 1316-1322.

55. Kim, H.S.; Kong, M.; Kim, K.; Kim, I.J.; Gu, H.B. Effect of carbon coating on $\mathrm{LiNi}_{1 / 3} \mathrm{Co}_{1 / 3} \mathrm{Mn}_{1 / 3} \mathrm{O}_{2}$ cathode material for lithium secondary batteries. J. Power Sources 2007, 171, 917-921.

56. Cao, Q.; Zhang, H.P.; Wang, G.J.; Xia, Q.; Wu, Y.P.; Wu, H.Q. A nvel carbon-coated $\mathrm{LiCoO}_{2}$ as cathode material for lithium-ion battery. Electrochem. Commun. 2007, 9, 1228-1232.

57. Hashem, A.M.A.; Abdel-Ghany, A.E.; Eid, A.E.; Trottier, J.; Zaghib, K.; Mauger, A.; Julien, C.M. Study of the surface modification of $\mathrm{LiNi}_{1 / 3} \mathrm{Co}_{1 / 3} \mathrm{Mn}_{1 / 3} \mathrm{O}_{2}$ cathode material for lithium-ion battery. J. Power Sources 2011, 196, 8632-8637.

58. Samarasingha, P.; Tran-Nguyen, D.-H.; Behm, M.; Wijayasinghe, A. $\mathrm{LiNi}_{1 / 3} \mathrm{Co}_{1 / 3} \mathrm{Mn}_{1 / 3} \mathrm{O}_{2}$ synthesized by the Pechini method for the positive electrode in Li-ion batteries: Material characteristics and electrochemical behavior. Electrochim. Acta 2008, 53, 7995-8000.

59. Zaghib, K.; Trudeau, M.; Guerfi, A.; Trottier, J.; Mauger, A.; Veillette, R.; Julien, C.M. New advanced cathode material: $\mathrm{LiMnPO}_{4}$ encapsulated with $\mathrm{LiFePO}_{4}$. J. Power Sources 2012, 204, $177-181$.

60. Minakshi, M.; Singh, P.; Appadoo, D.; Martin, D.E. Synthesis and characterization of olivine $\mathrm{LiNiPO}_{4}$ for aqueous rechargeable battery. Electrochim. Acta 2011, 56, 4356-4360.

61. Moorhead-Rosenberg, Z.; Shin, D.W.; Chemelewski, K.R.; Goodenough, J.B.; Manthiram, A. Quantitative determination of $\mathrm{Mn}^{3+}$ content in $\mathrm{LiMn}_{1.5} \mathrm{Ni}_{0.5} \mathrm{O}_{4}$ spinel cathodes by magnetic measurements. Appl. Phys. Lett. 2012, 100, 213909:1-213909:5.

62. Wu, H.M.; Belharouak, I.; Abouimrane, A.; Sun, Y.-K.; Amine, K. Surface modification of $\mathrm{Li}_{0.5} \mathrm{Mn}_{1.5} \mathrm{O}_{4}$ by $\mathrm{ZrP}_{2} \mathrm{O}_{7}$ and $\mathrm{ZrO}_{2}$ for lithium-ion batteries. Chem. Mater. 2010, 22, 587-603.

63. Goodenough, J.B.; Kim, Y. Challenges for rechargeable Li batteries. Chem. Mater. 2010, 22, 587-603.

64. Liu, D.; Han, J.; Dontigny, M.; Charest, P.; Guerfi, A.; Zaghib, K.; Goodenough, J.B. Redox behaviors of $\mathrm{Ni}$ and $\mathrm{Cr}$ different counter cations in spinel cathodes for Li-ion batteries. $J$. Electrochem. Soc. 2010, 157, A770-A775.

65. Liu, D.; Han, J.; Goodenough, J.B. Structure, morphology and cathode performance of $\mathrm{Li}_{1-\chi}\left[\mathrm{Ni}_{0.5} \mathrm{Mn}_{1.5}\right] \mathrm{O}_{4}$ prepared by coprecipitation with oxalic acid. J. Power Sources 2010, 195, 2918-2923. 
66. Liu, D.; Trottier, J.; Charest, P.; Fréchette, J.; Guerfi, A.; Mauger, A.; Julien, C.M.; Zaghib, K. Effect of nano $\mathrm{LiFePO}_{4}$ coating on $\mathrm{LiMn}_{1.5} \mathrm{Ni}_{0.5} \mathrm{O}_{4} 5 \mathrm{~V}$ cathode for lithium-ion batteries. J. Power Sources 2012, 204, 127-132.

67. Jang, I.C.; Lim, H.H.; Lee, S.B.; Karthikeyan, K.; Aravindan, V.; Kang, K.S.; Yoon, W.S.; Cho, W.I.; Lee, Y.S. Preparation of $\mathrm{LiCoO}_{2}$ and $\mathrm{LiFePO}_{4}$ coated $\mathrm{LiCoPO}_{4}$ materials with improved battery performance. J. Alloy. Compds. 2010, 497, 321-324.

68. Zaghib, K.; Dontigny, M.; Guerfi, A.; Charest, P.; Rodrigues, I.; Mauger, A.; Julien, C.M. Safe and fast-charging Li-ion battery with long shelf life for power applications. J. Power Sources 2011, 196, 3949-3954.

69. Zaghib, K.; Dontigny, M.; Guerfi, A.; Trottier, J.; Hamel-Paquet, J.; Gariepy, V.; Galoutov, K.; Hovington, P.; Mauger, A.; Groult, H.; Julien, C.M. An improved high-power battery with increased thermal operating range: $\mathrm{C}-\mathrm{LiFePO}_{4} / / \mathrm{C}-\mathrm{Li}_{4} \mathrm{Ti}_{5} \mathrm{O}_{12}$. J. Power Sources 2012, 216, 192-200.

70. Sloop, S.E.; Pugh, J.K.; Wang, S.; Kerr, J.B.; Kinoshita, K. Chemical reactivity of $\mathrm{PF}_{5}$ and $\mathrm{LiPF}_{6}$ in ethylene carbonate/dimethyl carbonate solutions. Electrochem. Solid-State Lett. 2001, 4, A42-A44.

71. Yang, H.; Zhuang, G.V.; Ross, P.N. Thermal stability of LiPF 6 salt and Li-ion battery electrolytes containing $\mathrm{LiPF}_{6}$. J. Power Sources 2006, 161, 573-579.

72. Pasquier, A.D.; Disma, F.; Bowmer, T.; Gozdz, A.S.; Amatucci, G.G.; Tarascon, J.M. Differential scanning calorimetry study of the reactivity of carbon anodes in plastic Li-ion batteries. J. Electrochem. Soc. 1988, 145, 472-482.

73. Zheng, T.; Gozdz, A.S.; Amatucci, G.G. Reactivity of the solid electrolyte interface on carbon electrodes at elevated temperatures. J. Electrochem. Soc. 1999, 146, 4014-4018.

74. Matsuo, Y.; Kostecki, R.; McLarnon, F. Surface layer formation on thin-film $\mathrm{LiMn}_{2} \mathrm{O}_{4}$ electrodes at elvated temperatures. J. Electrochem. Soc. 2001, 148, A687-A692.

75. Kopec, M.; Yamada, A.; Kobayashi, G.; Nishimura, S.; Kanno, R.; Mauger, A.; Gendron, F.; Julien, C.M. Structural and magnetic properties of $\mathrm{Li}_{x}\left(\mathrm{Mn}_{y} \mathrm{Fe}_{1-y}\right) \mathrm{PO}_{4}$ electrode material for Li-ion batteries. J. Power Sources 2009, 189, 1154-1163.

76. Lu, Y.; Shi, J.; Guo, Z.; Tong, Q.; Huang, W.; Li, B. Synthesis of $\mathrm{LiFe}_{1-\gamma} \mathrm{Ni}_{X} \mathrm{PO}_{4} / \mathrm{C}$ composites and their electrochemical performance. J. Power Sources 2009, 194, 786-793.

77. Wang, D.Y.; Wang, Z.X.; Huang, X.J.; Chen, L.Q. Continuous solid-solutions $\mathrm{LiFe}_{1-x} \mathrm{Co}_{x} \mathrm{PO}_{4}$ and its electrochemical performance. J. Power Sources 2005, 146, 580-583.

78. Zhang, Y.; Sun, C.S.; Zhou, Z. Sol-gel preparation and electrochemical performances of $\mathrm{LiFe}_{1 / 3} \mathrm{Mn}_{1 / 3} \mathrm{Co}_{1 / 3} \mathrm{PO}_{4}$ composites with core-shell nanostructure. Electrochem. Commun. 2009, 11, 1183-1186.

79. Daniel, L.; Martinet, S.; Gutel, T.; Bourbon, G.; Radvanyi, E.; Amuntencei, M.; Patoux, S. Iron substitution to increase energy density of lithiated phosphates. In Proceeding of the 222th ECS Meeting, Honolulu, HI, USA, 7-12 October 2012.

80. Minakshi, M.; Singh, P. Olivine type $\mathrm{LiMn}_{1 / 3} \mathrm{Co}_{1 / 3} \mathrm{Ni}_{1 / 3} \mathrm{PO}_{4}$ cathode for secondary battery applications. In Proceeding of the 222th ECS Meeting, Honolulu, HI, USA, 7-12 October 2012. 
81. Wang, X.J.; Yu, X.Q.; Li, H.; Yang, X.Q.; McBreen, J.; Huang, X.J. Li-storage in $\mathrm{LiFe}_{1 / 4} \mathrm{Mn}_{1 / 4} \mathrm{Co}_{1 / 4} \mathrm{Ni}_{1 / 4} \mathrm{PO}_{4}$ solid solution. Electrochem. Commun. 2008, 10, 1347-1350.

82. Oh, S.; Myung, S.; Park, J.; Scrosati, B.; Amine, K.; Sun, Y. A novel double-structured $\mathrm{LiMn}_{0.85} \mathrm{Fe}_{0.15} \mathrm{PO}_{4}: \mathrm{LiFePO}_{4}$ core-shell materials for rechargeable lithium-ion batteries. In Proceeding of the 222th ECS Meeting, Honolulu, HI, USA, 7-12 October 2012.

83. Kim, W.-S.; Kim, S.-B.; Jang, I.C.; Lim, H.H.; Lee, Y.S. Remarkable improvement in cell safety for $\mathrm{Li}\left[\mathrm{Ni}_{0.5} \mathrm{Co}_{0.2} \mathrm{Mn}_{03}\right] \mathrm{O}_{2}$ coated with $\mathrm{LiFePO}_{4}$. J. Alloy. Compds. 2010, 492, L87-L90.

84. Huggins, R.A. Do you really want an unsafe battery? In Proceeding of Pacific Rim Meeting on Electrochemical and Solid-State Science (PRIME) of the 222th ECS Meeting, Honolulu, HI, 7-12 October 2012.

85. Xu, K.; Angell, C.A. Sulfone-based electrolytes for Li-ion batteries. J. Electrochem. Soc. 2002, 149, A920-A926.

86. Han, D.-W.; Kang, Y.-M.; Yi, R.-Z.; Song, M.-S.; Kwon, H.-S. Effects of Fe doping on the electrochemical performance of $\mathrm{LiCoPO}_{4} / \mathrm{C}$ composites for high-power density cathode materials. Electrochem. Commun. 2009, 11, 137-140.

87. Chebiam, R.V.; Prado, F.; Manthiram, A. Soft chemistry synthesis and characterization of layered $\mathrm{Li}_{1-x} \mathrm{Ni}_{1-y} \mathrm{Co}_{y} \mathrm{O}_{2}(0 \leq x \leq 1$ and $0 \leq y \leq 1)$. Chem. Mater. 2001, 12, 2951-2957.

88. Venkatraman, S.; Manthiram, A. Synthesis and characterization of P3-type $\mathrm{CoO}_{2}$. Chem. Mater. 2002, 14, 3907-3912.

89. Nyten, A.; Abouimrane, A.; Armand, M.; Gustaffson, T.; Thomas, J.O. Electrochemical performance of $\mathrm{Li}_{2} \mathrm{FeSiO}_{4}$ as a new Li-battery cathode element. Electrochem. Commun. 2005, 7, 156-160.

90. Zaghib, K.; Ait-Salah, A.; Ravet, N.; Mauger, A.; Gendron, F.; Julien, C.M. Structural, magnetic and electrochemical properties of lithium iron orthosilicate. J. Power Sources 2006, 160, 1381-1386.

91. Dominko, R.; Bele, M.; Gaberscek, M.; Meden, A.; Remska, M.; Jamnik, J. Structure and electrochemical performance of $\mathrm{Li}_{2} \mathrm{MnSiO}_{4}$ and $\mathrm{Li}_{2} \mathrm{FeSiO}_{4}$ as potential Li-battery cathode materials. Electrochem. Commun. 2006, 8, 217-222.

92. Chung, Y.; Yu, S.; Song, M.S.; Kim, S.-S.; Cho, W.I. Structural and electrochemical properties of $\mathrm{Li}_{2} \mathrm{Mn}_{0.5} \mathrm{Fe}_{0.5} \mathrm{SiO}_{4} / \mathrm{C}$. Bull. Korean Chem. Soc. 2011, 32, 4205-4209.

93. Xiao, Y.-L.; Gong, Z.; Yang, Y. Synthesis and characterization of $\mathrm{Li}_{2} \mathrm{MnSiO}_{4} / \mathrm{C}$ nanocomposite cathode material for lithium-ion batteries. J. Power Sources 2007, 174, 528-532.

94. Dominko, R. $\mathrm{Li}_{2} \mathrm{MSiO}_{4}(M=\mathrm{Fe}$, and/or Mn) cathode. J. Power Sources 2008, 184, 462-468.

95. Rangappa, D.; Murukanahally, K.D.; Tomai, T.; Unemoto, A.; Honma, I. Ultrathin nanosheets of $\mathrm{Li}_{2} \mathrm{MSiO}_{4}(M=\mathrm{Fe}, \mathrm{Mn})$ as high-capacity Li-ion battery electrode. Nano Lett. 2012, 12 , $1146-1151$.

(C) 2013 by the authors; licensee MDPI, Basel, Switzerland. This article is an open access article distributed under the terms and conditions of the Creative Commons Attribution license (http://creativecommons.org/licenses/by/3.0/). 